\title{
Risks and opportunities associated with pollinators' conservation and management of pollination services in Latin America
}

\author{
Leonardo Galetto ${ }^{1, \mathbb{D}}$; Marcelo A. Aizen $^{2} ;$ M. Del Coro Arizmendi ${ }^{3}$; Breno M. \\ Freitas; ; Lucas A. Garibaldi ${ }^{5}$; Tereza C. Giannini ${ }^{6}$; Ariadna V. Lopes"; Mário \\ M. Do Espírito Santo; Márcia M. Maués; Guiomar Nates-Parra ${ }^{10}$; Jaime I. \\ RodrígueZ ${ }^{11}$; José J. G. Quezada-EuÁn ${ }^{12}$; Remy Vandame ${ }^{13}$; Blandina F. Viana ${ }^{14}$ \\ \& Vera L. IMPERATRIZ-FonseCA ${ }^{6}$
}

${ }^{1}$ Departamento de Diversidad Biológica y Ecología, FCEF y Naturales, Universidad Nacional de Córdoba (UNC) - Consejo Nacional de Investigaciones Científicas y Técnicas (IMBIV), Córdoba, Argentina. **

\begin{abstract}
Aвstract. The conservation status of pollinators and pollination in Latin America (LA) is reviewed. The knowledge regarding native and managed pollinators (e.g., honeybee and stingless bees) and pollination services was synthetized, and the guidelines to improve the opportunities for conservation are provided, considering the threats to pollinators and the perspectives from traditional and local knowledge. The analysis indicates that diverse threats (e.g., large-scale agriculture, deforestation, overuse of agrochemicals) are linked with pollination and pollinator decline, which affect the reproduction of most native plants and the yields of many crops. LA harbours the highest bee diversity worldwide, with $26 \%$ of the total recorded species, and it is a biodiversity hotspot of vertebrate pollinators, including hummingbirds, perching birds, nectarivorous bats and other mammal pollinators. Specific recommendations to conserve native pollinators and to improve pollination services are provided, which could be considered by stakeholders and governments aiming to elaborate biocultural conservation. For example, introducing policies and legal responses for incentives to help farmers maintain natural habitats and forests, to replace or reduce agrochemicals and to improve diversified crop production with agroecological practices; refining agrochemical regulations to minimize the exposure of pollinators to insecticides and herbicides; improving knowledge and education on pollinators and pollination gives societies worldwide the opportunity to change current hegemonic agricultural practices and consumption patterns; integrating different land ethical views of ethnic minorities on a sustainable relationship between production and biodiversity. A wider view combining social, ecological, cultural dimensions may support better decision making. This holistic socio-agroecological perspective is urgently needed to conserve and manage pollinators at different spatial and temporal scales, and to integrate pollination services, pollinator-friendly habitat management approaches and diversified farming systems.
\end{abstract}

[Keywords: biodiversity, environmental policies, pollination deficit, pollinator decline, pollination services, traditional local knowledge]

Resumen. Riesgos y oportunidades asociados a la conservación de los polinizadores y a la gestión de los servicios de polinización en América Latina. Se realizó una revisión sobre el estado de conservación de los polinizadores y la polinización en América Latina (LA). Se presentan pautas para mejorar las oportunidades de conservación, considerando las amenazas a los polinizadores y las perspectivas desde el conocimiento tradicional y local. El análisis indica que diversas amenazas (e.g., agricultura a gran escala, deforestación, uso excesivo de agroquímicos) están vinculadas con la disminución de polinizadores, afectando la reproducción de las plantas nativas y los rendimientos de muchos cultivos. LA alberga la mayor diversidad de abejas en todo el mundo y una gran diversidad de polinizadores vertebrados (e.g., colibríes, aves de percha nectarívoras, murciélagos nectarívoros y otros mamíferos). Se proporcionan recomendaciones para proteger los polinizadores nativos y mejorar los servicios de polinización, las que podrían ser consideradas por los tomadores de decisiones y así promover la conservación biocultural. Por ejemplo, desarrollar instrumentos legales, políticas e incentivos para ayudar a los agricultores a mantener los hábitats naturales, para reemplazar o reducir el uso de agroquímicos y para promover las prácticas agroecológicas; perfeccionar las reglamentaciones sobre aplicación de agroquímicos para minimizar la exposición de los polinizadores a insecticidas y herbicidas; mejorar la comunicación pública del conocimiento sobre los polinizadores y la polinización para incentivar un cambio en las prácticas agrícolas hegemónicas y los patrones de consumo actuales; considerar otras éticas ambientales de las minorías étnicas para enfatizar la necesidad de promover una relación sostenible entre producción de alimentos y biodiversidad. Se necesita urgentemente una visión más amplia que combine las dimensiones sociales, ecológicas y culturales para una mejor toma de decisiones. Esta perspectiva socio-agroecológica holística es importante para conservar y gestionar los polinizadores a diferentes escalas espaciales y temporales, y para poder integrar los servicios de polinización con enfoques de gestión del territorio favorables a los polinizadores y con sistemas agrícolas diversificados.

[Palabras clave: biodiversidad, políticas ambientales, déficit de polinización, disminución de polinizadores, servicios de polinización, conocimiento local tradicional]

Editora asociada: Ana Cingolani

Recibido: 8 de Junio de 2021

Editor junior: Alejandro Loydi 
${ }^{*}$ Laboratorio Ecotono, INIBIOMA, Universidad Nacional del Comahue-CONICET, Río Negro, Argentina. ${ }^{3}$ Universidad Nacional Autónoma de México, Tlalnepantla, México, México. ${ }^{4}$ Universidade Federal do Ceará, Departamento de Zootecnia, Setor de Abelhas, Fortaleza, Ceará, Brazil. ${ }^{5}$ Universidad Nacional de Río Negro, Instituto de Investigaciones en Recursos Naturales, Agroecología y Desarrollo Rural, Río Negro, Argentina. Consejo Nacional de Investigaciones Científicas y Técnicas, and Instituto de Investigaciones en Recursos Naturales, Agroecología y Desarrollo Rural, Río Negro, Argentina. ${ }^{6}$ Instituto Tecnológico Vale Desenvolvimento Sustentavel, Belem, Para, Brazil. ${ }^{7}$ Departamento de Botánica, Universidade Federal de Pernambuco, Recife, Pernambuco, Brazil. ${ }^{8}$ Departamento de Biologia Geral/CCBS Universidade Estadual de Montes Claros, MG, Brasil. ${ }^{9}$ Embrapa Amazônia Oriental, Laboratório de Entomologia, Belém, Pará, Brazil. ${ }^{10}$ Universidad Nacional de Colombia, Bogotá DC, Colombia. ${ }^{11}$ Museo Nacional de Historia Natural de Bolivia, La Paz, Bolivia. ${ }^{12}$ Departamento de Apicultura Tropical-FMVZ-Universidad Autónoma de Yucatán, Mérida, México. ${ }^{13}$ El Colegio de la Frontera Sur, San Cristóbal de las Casas, Chiapas, México. ${ }^{14}$ Universidade Federal da Bahia, Salvador, Bahia, Brazil.

\section{INTRODUCTION}

Pollinators provide a wide spectrum of benefits that support human well-being, as they contribute to maintain the populations of most wild plants by securing their reproduction and promoting their genetic diversity (IPBES 2016). Furthermore, pollinators promote fruit and seed set of many crops that feed humanity with vital micronutrients (e.g., vitamins, minerals, carotenoids), while also play an important role in the integrity of ecosystem functioning of natural habitats (e.g., Eilers et al. 2011; Smith et al. 2015; Ghosh and Jung 2018). In addition, pollinators are deeply related to cultural and spiritual values of human communities (IPBES 2016; QuezadaEuán et al. 2018; Hill et al. 2019).

Most pollinators are insects, such as bees, flies, butterflies, moths, wasps, and beetles, but also include perching birds, hummingbirds, bats and other mammals (e.g., Buchmann and Nabhan 1996; Kevan 1999). Bees are considered the most important group of flower visitors because they pollinate $40-50 \%$ of all angiosperms; some can be managed for use in agriculture in Latin America (LA) (Freitas et al. 2009; IPBES 2016), such as the exotic honeybee (Apis mellifera) and many native bees (Vandame and Palacio 2010; Giannini et al. 2015; Maggi et al. 2016). For example, different bee species pollinate $66 \%$ of the Brazilian crops (Wolowski et al. 2019).

Latin America (all countries from South and Central America, the Caribbean and México) includes unique and impressive tropical, subtropical and temperate biomes with high landscape heterogeneity, supporting great natural and cultural diversity (e.g., QuezadaEuán et al. 2018). At the same time, LA shows deforestation rates close to global levels, with Brazil and Indonesia accounting for a great amount of tropical forest loss between 1980 and 2005 (Achard et al. 2002). A forest loss of $>50$ Mha was registered in LA for the period 2001-2011, with more than 30 Mha of deforestation occurring in Brazil (Pendrill and Persson 2017). Latin America is also a great global producer of commodities (i.e., a raw material or primary agricultural product that can be bought and sold in international markets, such as soybean, maize or coffee), with vast areas of natural vegetation converted into agricultural farmlands (e.g., Lapola et al. 2014; le Polain de Waroux et al. 2018). High and continuous deforestation was registered in Chile, Argentina, Ecuador, Paraguay, Brazil and México during the period 1980-2010, with the expansion of agriculture and cattle grazing lands as the mainly direct drivers (Armenteras et al. 2017). This scenario implies the occurrence of socioecological trade-offs affecting nature and people through many threats. For example, rapid land use changes drive the loss of biocultural diversity through habitat destruction and fragmentation, which impact many ecological processes (Grez and Galetto 2011). In addition, direct (i.e., those determining habitat loss) and indirect (i.e., those non-targeted harms also affecting biodiversity) threats for pollinators also exist, including the intensification of largescale agriculture, the increasing application of pesticides, and the occurrence of invasive species, pathogens and climate change (Freitas et al. 2009; Vandame and Palacio 2010; Giannini et al. 2017; FAO 2019; Wolowski et al. 2019), which can additively trigger pollinators decline and pollination deficits among native plants and many crops (Lopes et al. 2009; Ferreira et al. 2015; Hipólito et al. 2018). The increases in pesticide application have been markedly different among continental regions (Vryzas et al. 2020). In Europe and North America, the total amount of pesticide application per year was stable between 1990 and 2018 (around 0.45-0.50Mton/year), but continuous increases were registered in Africa, Asia and Central America (25, 95 and 97\%, respectively), and markedly in South America (>480\%) (FAO 2019).

Decision-making processes involve the values, beliefs and perspectives of different 
social actors, with conflicts arising from the disputed habits on the environment (Rozzi 2013). Nevertheless, which values are highlighted or obscured may change according to the perspectives of the different stakeholders (Galetto et al. 2019). Many economic and environmental indicators cannot capture the benefits of pollinators and pollination for humans or the full costs of intensified agriculture because they mainly focus on crop yields and disregard environmental externalities (Galetto et al. 2018; Hill et al. 2019). However, sound decision making should reflect the plurality of the values and perspectives of the societies in which it occurs.

Developing nations usually rely on extractive land uses (e.g., industrial forestry and agriculture and large-scale mining) for the economic development of a minor proportion of the society by accumulation by dispossession (Harvey 2003), causing the conversion of natural ecosystems to new landscapes, threatening biodiversity and affecting mostly people with low incomes (Cáceres 2015;Pengue2016). Therefore, seeking a more sustainable and socially fair transition pathway from this model becomes an issue of primary importance (Pengue 2005; Pengue and Altieri 2005). The consideration of the status of pollinators and the threats affecting pollination and the food production system in LA may lead to improved biodiversity conservation in developing countries.

Briefly, we review the evidence regarding the status, trends and threats for pollinators and pollination services in LA, integrating responses from different cultural views and values. For this reason, we include some perspectives developed according to the traditional and local knowledge (TLK) of Latin American cultures regarding pollinators, pollination and ecosystem management. We highlight the particularities of the conservation of pollinators and pollination services in this megadiverse region because it is threatened by different drivers; nevertheless, TLK could be part of the solution, specifically when considering diverse biocultural and socioeconomic contexts. We summarize knowledge gaps and propose some recommendations to improve the management and conservation of pollinators and pollination. We argue that the lessons and management implications regarding the trade-offs, risks and opportunities related to pollinators and pollination in LA may also be useful elsewhere because the megadiverse tropical and subtropical regions of the world mostly occur within countries producing commodities linked to biodiversity loss.

\section{DIVERSITY OF POLLINATORS AND KNOWLEDGE STATUS}

Wild pollinators depend on native plants for foraging (Figure 1), nesting and reproduction, indicating that complex ecological interactions

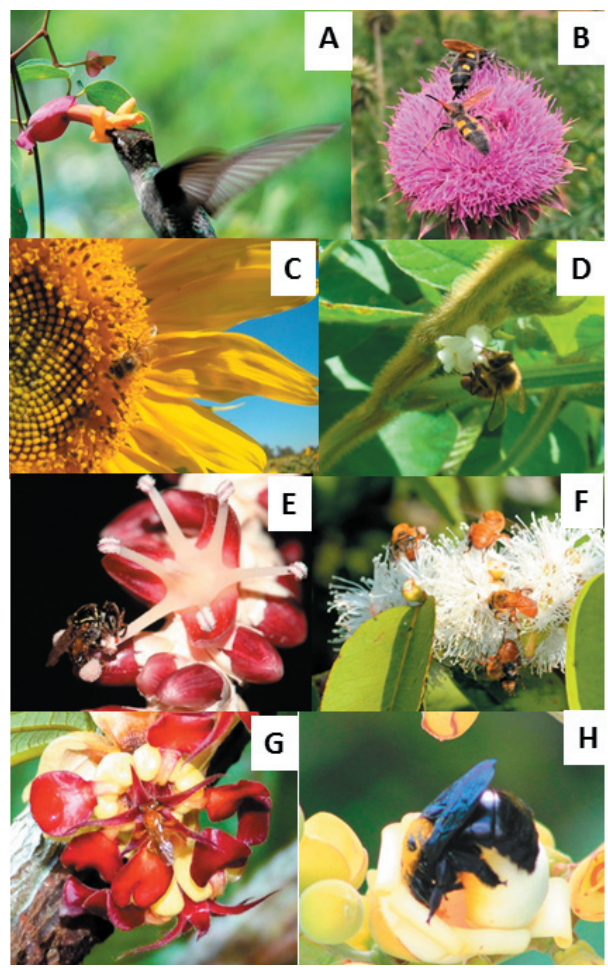

Figure 1. Pollinators of native, exotic-invasive plants and some crops in Latin America. (A) Heliomaster furcifer visiting flowers of Dolichandra cynanchoides. (B) Wasps (Scoliidae) on the exotic-invasive Carduus sp. (C) Apis mellifera on sunflower. (D) Apis mellifera on soybean. (E) Plebeia minima (mosquito bee) in a male Euterpe oleracea (açai or assai) flower (photo credit: Cristiano Menezes). (F) Stingless bees (Meliponina) in Myrciaria dubia (camucamu) flowers. (G) Trigona pallens (stingless bee) in Theobroma grandiflorum (cupuassu) flower. (H) Xylocopa frontalis (carpenter bee) in Bertholletia excelsa (Brazil nut) flower.

Figura 1. Polinizadores de plantas nativas, exóticas invasoras y algunos cultivos en Latinoamérica. (A) Heliomaster furcifer visitando flores de Dolichandra cynanchoides. (B) Avispas (Scoliidae) en flores de una especie exótica-invasora de Carduus sp. (C) Apis mellifera en flores de girasol. (D) Apis mellifera en una flor de soja. (E) Plebeia minima (abeja mosquito) en una flor masculina de Euterpe oleracea (açai or assai) (crédito: Cristiano Menezes). (F) Abeja sin aguijón (Meliponina) en flores de Myrciaria dubia (camucamu). (G) Trigona pallens (abeja sin aguijón) en flores de Theobroma grandiflorum (cupuassu). (H) Xylocopa frontalis (abeja carpintera) en flores de Bertholletia excelsa (nuez de Pará o nuez de Brasil). 
exist at the landscape level. Latin America shows one of the highest plant species richness, mainly for tropical and subtropical forest biomes (Kier et al. 2005). This evidence for plant richness is relevant for the estimation of pollinator richness in LA because Ollerton (2017), when analysing data from 65 sites around the world, showed a strong positive correlation between the number of plant species in a given community and the number of associated flower visitors (see Figure 4 of Ollerton 2017). Although a great pollinator richness is hypothesized based on this base (Kier et al. 2005; Ollerton 2017), there is scattered recorded evidence for different groups of pollinators in LA. For example, LA harbours the highest bee diversity worldwide, with $26 \%$ of the $>20000$ recorded species (Orr et al. 2021). South America is also a biodiversity hotspot of vertebrate pollinators, such as mammals and birds (Jenkins et al. 2013), including hummingbirds, perching birds, nectarivorous bats and other mammal pollinators (Buzato et al. 2012). Hummingbirds form a diverse group, with the highest richness in South America (McGuire et al. 2014), capable of foraging among a variety of flowers (Figure $1 \mathrm{a}$ ) and habitats (Arizmendi et al. 2016). Moths are a well-studied group of pollinators of the Sphingidae family with a global richness of 1400 species, with $>300$ species registered in South America (Avila et al. 2012; de Camargo et al. 2018). A recent review on the number of cases of double mutualisms (pollination and seed dispersal) in the different biogeographic regions of the word showed that the Neotropical region registered $44.3 \%$ of the cases, which positively impact on the ecosystem functioning (Fuster et al. 2019).

Bees are involved in the pollination of most native and exotic plant species (Figure $1 \mathrm{~b}$ h), but also of many crops (Figure $1 \mathrm{c}, \mathrm{d}, \mathrm{h}$ ) (Freitas et al. 2009; Giannini et al. 2015; Klein et al. 2020). Native bees can be found in every known biome all over LA. A major problem is the lack of information on their richness, diversity, taxonomy, distribution, population dynamics and the impacts of human activities (Moure et al. 2007; Freitas et al. 2009; Orr et al. 2021). Some of the difficulties that impede identifying diversity baselines for pollinators and, consequently, their conservation management could be related to the hyperdiverse plant-pollinator communities, combined with the scant financial resources available to support scientific work and the implementation of taxonomic inventories (Yurrita et al. 2017). Moreover, there is comparatively scarce knowledge on the plant-pollinator interactions or regarding their specific threats. Nevertheless, nectarivorous bats and hawkmoths involved in pollination are mostly found in old-growth forests (Gonçalves et al. 2017), and most of the conservation challenges faced by these groups are related to deforestation. At the same time, the highest number of data-deficient species occurs in the Amazon basin (Frick et al. 2019). Bats, however, provide ecosystem services of major socio-economic importance by, for example, pollinating crops (e.g., Stenocereus queretaroensis) in semi-arid regions as the columnar cacti in central México (Tremlett et al. 2020). Recently, in Colombia, the fauna of nectarivorous bats is being known in different regions of the country, as well as data on their interaction with plants (Mantilla-Meluk et al. 2014; Mora-Beltran and López-Arévalo 2018; Echavarría et al. 2018). This has made people know the importance of these organisms as pollinators and does not continue to exterminate them.

\section{Current status of managed bees}

Currently, only a few native bees are managed in LA (mostly stingless bees; see below). Like elsewhere, the introduced Honeybee (Apis mellifera) is the most widely used bee species. Beekeeping thrives throughout LA, and countries such as Argentina, México and Brazil are among the world's largest honey producers and exporters, despite poor colony management (IPBES 2016; Maggi et al. 2016). A recent review on honeybee health in five countries (Argentina, Chile, Uruguay, Brazil and Venezuela) analysed colony losses and causes of colony mortality. The study showed that colony losses per year ranged from 30 to $35 \%$ for professional beekeepers (up to 50\% for nonprofessional beekeepers) with no single explanation, possibly because there are different stressors that synergistically interact (Maggi et al. 2016). Varroa destructor prevalence (estimated for adult bees) and honeybee viral diseases seem to be the main stressors affecting 20 to $100 \%$ of the colonies (Maggi et al. 2016). Although pollination by honeybees improves agricultural crop yields and could improves the financial incomes of beekeepers by increasing honey production and by hive rental revenues, in general and with a few exceptions, these benefits have been neglected in LA because beekeepers are 
more interested in honey production than in moving their hives for agricultural pollination (e.g., Dos Santos et al. 2018).

In addition to beekeeping with Apis mellifera, the production of honey has been practiced with different species of native stingless bees by civilizations such us the Nahuatl and Maya from México since pre-Columbian times (Quezada-Euán et al. 2001). Recently, studies of stingless bees (e.g., Bomfim et al. 2014; Viana et al. 2014) as well as bumble bees (e.g., TorresRuiz and Jones 2012) and solitary bees (e.g., Magalhães and Freitas 2013) for the pollination of different crops are steadily increasing across LA. However, the dependence on wild populations can become a threat for the conservation status of species used for crop pollination. The development of techniques to breed, to manage, and to promote quick population growth of these pollinators are needed. For instance, the increasing popularity of stingless bees has quick rise in the demand for colonies which surpasses the supply from managed populations. Stingless beekeeping practices still need to be better developed, particularly in terms of mass reproduction of colonies (Jaffé et al. 2016).

\section{CRop DePendence on POLlinator SERVICES}

Provisioning resources and ecosystem services (ES) are essential to human societies, and the trade-offs between pollination and crop yield are thus a major concern. Large regions and biomes have suffered dramatic land use changes mainly due to large-scale agriculture, which is supported by various laws approved by LA governments (e.g., for transgenic crops, seed patents and agrochemicals) (Leguizamón 2014; Pengue 2016). In LA, the land area devoted to agriculture has expanded by ca. 130\% since 1961 (Figure 2). Nearly 70\% of this growth is related to the cultivation of pollinator-dependent crops (Figure 2), mostly soybean (Glycine max) (Figure $1 \mathrm{~d}$ ). The cultivation of soybean has increased dramatically, accounting for approximately $65 \%$ of the expansion of land used for agriculture over natural habitats (Figure 3). Some soybean varieties can increase in yield by 18 to $50 \%$ when the flowers are visited by bees (e.g., Milfont et al. 2013; Huais et al. 2020). Overall, the expansion of large-scale agriculture has decreased biodiversity in general, and pollinator diversity in particular (IPBES 2016; Dycks et al. 2021).

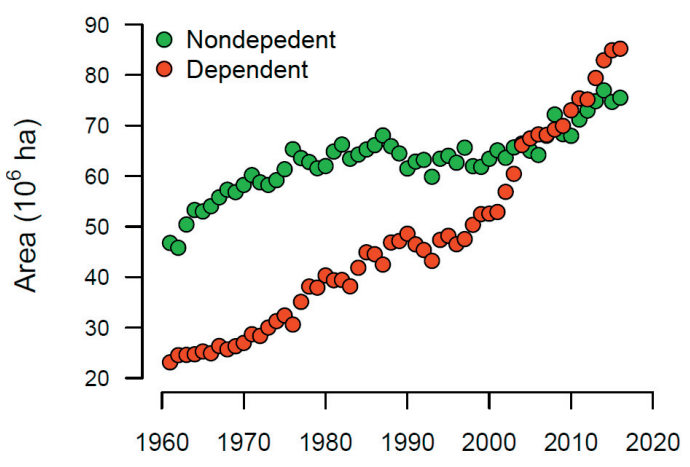

Year

Figure 2. Expansion of agricultural land devoted to pollinator-dependent and nondependent crops during recent decades in Latin America. The most abundant pollinator-dependent crop in 2016 was soybean, explaining the large increase in the pollinator dependence of LA agriculture. In 1961, this crop accounted for only $0.4 \%$ of the total agricultural land, whereas in 2016, this percentage increased to $36.7 \%$, mostly through the conversion of natural habitats.

Figura 2. Expansión de tierras agrícolas dedicadas a cultivos dependientes y no dependientes de polinizadores durante las últimas décadas en América Latina. El cultivo dependiente de polinizadores más abundante en 2016 fue la soja, lo que explica el gran aumento en la dependencia de polinizadores de la agricultura latinoamericana. En 1961, este cultivo representaba sólo $0.4 \%$ del total de tierras agrícolas, mientras que en 2016, este porcentaje aumentó al $36.7 \%$, principalmente a través de la conversión de hábitats naturales.

The cultivated area of several cash crops with high market value and great dependence on pollinatorshasincreased from one-tothree-fold in LA during the last five decades (FAOSTAT 2017). For example, the Brazil nut (Bertholletia excelsa) and the açaí palm (Euterpe oleracea) are cultivated in the Amazon region, and crop production is dependent on native bees as pollinators (Campbell et al. 2018; Cavalcante et al. 2018; Bezerra et al. 2020) (Figure 1 h). Some species of passionflower, such as passion fruit (Passiflora edulis f. flavicarpa), are clear examples of the dependence of an industrial crop on the presence of wild bees to increase productivity (Camilo 2003; Calle et al. 2010; Yamamoto et al. 2012). In particular, passion fruit presents self-incompatibility and flowers need to be visited and pollinated by large bees, such as carpenters of the genus Xylocopa, to produce fruits. In Colombia, research has been carried out on other passion flowers, which represent sources of income for local communities, such as the cholupa (Passiflora maliformis), which is the only fruit with denomination of originprotection in the country. Like other passion flowers, this species depends on bees, $A$. 
1961

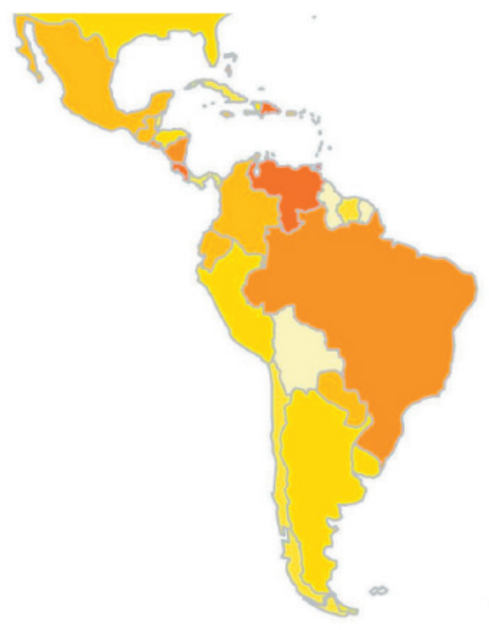

2016

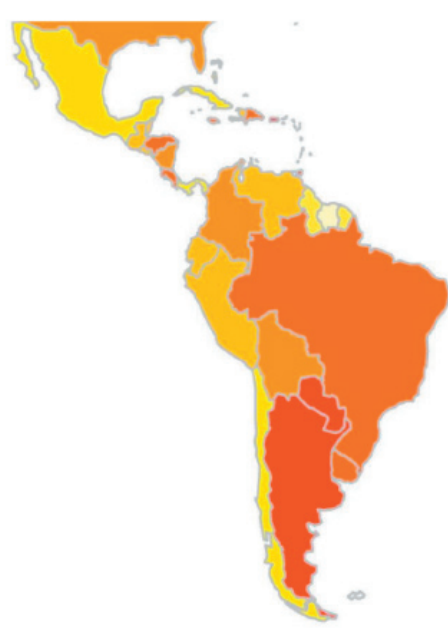

Figure 3. Map of Latin America showing agricultural dependence on pollinators (i.e., the proportion of expected agricultural production loss in the absence of animal pollinators: categories depicted according to the coloured bar) in 1961 and 2016 based on the FAO dataset (FAOSTAT 2017)

Figura 3. Mapa de América Latina que muestra la dependencia agrícola de los polinizadores (i.e., la proporción de pérdida de producción agrícola esperada en ausencia de polinizadores bióticos; categorías representadas según la barra de color) en 1961 y 2016 según el conjunto de datos de la FAO (FAOSTAT 2017). mellifera being the most frequent, but not the most effective pollinator. Large bees such as Xylocopa, Centris and Epicharis, among others, manage to contact the reproductive structures of the flowers, ensuring their complete pollination with just one visit (Ospina-Torres et al. 2010).

Although most crops can benefit from the presence of diverse pollinator assemblages, pollinator-dependent crops in conventional agricultural landscapes rely mostly on managed and feral honeybees for pollination (e.g., grapefruit [Chacoff and Aizen 2006], sunflower [Sáez et al. 2012], apple [Viana et al. 2014; Geslin et al. 2017], canola [Witter et al. 2015; Mazzei et al. 2021], coffee [Hipólito et al. 2018; Giannini et al. 2015], melon [Bomfim et al. 2014] and cucurbit [Bomfim et al. 2016]), mainly because intensified agricultural practices do not include the creation of pollinator-friendly landscapes.

\section{TRADITIONAL LOCAL KNOWLEDGE ON POLLINATORS AND POLLINATION}

In recent years, attention has been paid to the value and protection of native bees and other pollinators, with an increased interest in TLK associated with biodiversity and crop production (IPBES 2016). Experience gained over centuries of interaction with the environment has shaped human knowledge across different groups and societies. As a result, the intricate link between ecosystem management and cultural values has produced rich and diverse TLK systems all over the world (e.g., Quezada-Euán et al. 2018; Hill et al. 2019). Traditional and local knowledge is particularly widespread in LA; local communities have been able to identify different bee species, their nests and a variety of honey types with different tastes and medicinal properties since at least 1400 years ago (Quezada-Euán et al. 2018 and references therein).

In particular, meliponiculture (beekeeping with stingless bees) has been performed for centuries by local communities in LA (Quezada-Euán et al. 2018). The TLK on stingless bees is important for the establishment of conservation strategies for many species because local communities can classify bees according to their morphological, behavioural and ecological characteristics, providing extensive TLK for environmental management (Carvalho et al. 2014). For example, TLK acknowledges that remnant environments with trees that form dense vegetation and with abundant water resources are preferred by stingless bees. Consequently, beekeepers maintain some of the native plants from such environments in their crop lands for bees (Carvalho et al. 2014). 
Many indigenous cultures in LA know and use the environment on the basis of different agricultural practices that can benefit pollinators (Quezada-Euán et al. 2018). For example, local farmers use their TLK to manage useful plant resources (medicinal or edible native plants that are usually classified as weeds), maintaining a large variety of crops within their fields (beans, chili pepper, citrus, melon, papaya, squash, tomato, watermelon, etc., which depend on pollinators to produce fruits), indicating that small-scale agriculture can be compatible with the conservation of pollinator biodiversity, although indigenous and rural people do not perceive the relationships among weeds, pollinators and crop reproduction (Blanckaert et al. 2007). Indigenous communities in Central America relocate bees into fallow areas to accelerate both pollination and honey making; when forest stands have matured and trees have aged 10 to 25 years, bee colonies are located in this secondary forest to aid in pollination and to take advantage of the many flowering plant species (Diemont et al. 2011). This management of pollinators and bee colonies shows that agroforestry could be a component of landscape planning, sustainable production and biodiversity conservation. However, other indigenous communities in LA have perceived the continuous pollinator decline that has occurred during recent decades, including the risks regarding crop pollination and the implications for agricultural production (Quezada-Euán et al. 2018; Hill et al. 2019). Another example of the rescue of TLK about stingless bees was generated in the eastern plains of Colombia, with a work of recognition, learning and dissemination of traditional knowledge about Melipona favosa among the 'llanera', a community made up of 25 families. The community is led by a man over 70 years old, whose knowledge of this stingless bee species was inherited from his parents and grandparents (Nates-Parra and Ramírez 2020).

These examples indicate that TLK regarding pollinators and pollination is complex and involves all beings in nature, including humans (Quezada-Euán et al. 2018; Hill et al. 2019). In some locations, bees are considered to be the beings that make possible the continuation of all life in the universe, and honey is associated with fertility and procreation (Falcheti and Nates-Parra 2002). It is important to recognize that scientific knowledge and TLK are usually developed under different epistemological and ethical understandings of human-nature relationships. In general, nature is perceived as a separate entity in Western societies and considered to be at humans' service. Under a different view, indigenous societies see humans as a part of nature contributing to eco-social justice through the conservation of biological and cultural diversity (Galetto et al. 2019). TLK and associated land-use practices complement scientific research, shedding light on new questions or perspectives and providing methods for managing pollinators within biodiverse agricultural systems. The huge differences in cultural perceptions of nature and pollinators must be integrated to improve the management of natural habitats.

\section{THREATS TO THE CONSERVATION OF POLLINATORS AND POLLINATION}

\section{Risks caused by deforestation and habitat fragmentation}

Deforestation is a major threat affecting the conservation of pollinator diversity and pollination services in LA. Major biomes in Central (e.g., dry and humid forests) and South America (e.g., Amazonia, Atlantic Forest, Caatinga, Cerrado and Chaco) have suffered intense deforestation in recent years, mainly due to large-scale industrial agroforestry (Fehlenberg et al. 2017; Molin et al. 2017; Yanai et al. 2017). For example, when analysing deforestation rates per country in LA during the period 1990-2010, Argentina, Chile, Ecuador and Paraguay showed the highest deforestation rates (Armenteras et al. 2017). During the period 2001-2011, LA lost more than 50 Mha of forests, mostly in Argentina, Bolivia, Brazil, Colombia, México, Paraguay and Perú (Pendrill and Persson 2017). When combining deforestation rates and the amount of forest loss for LA countries, a clear generalized picture can be evidenced with moderate to high deforestation for the entire region (Figure 4). The two main direct drivers explaining deforestation are agricultural expansion for crops and cattle raising (Armenteras et al. 2017; Pendrill and Persson 2017). Nevertheless, most countries in LA present one of these two drivers or both related to forest loss (Pendrill and Persson 2017) (Figure 5). There are three hotspots of deforestation during the last 20 years, the Chaco biogeographic region in Northern Argentina, Bolivia and Paraguay, the Cerrado in Brazil and the Amazon. The Chaco and 


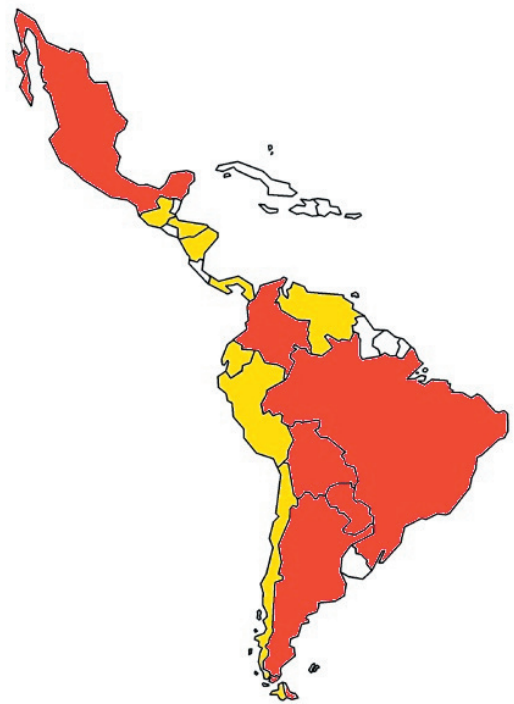

Figure 4. Map of Latin America showing the impact of deforestation rates and forest loss during the last decades using combined data from Armenteras et al. (2017) and Pendrill and Persson (2017). Countries in red exhibited high rates of deforestation and forest loss; in yellow, moderate rates of deforestation or forest loss, and in white, low rates of deforestation, or minor forest lost or data not available.

Figura 4. Mapa de América Latina que muestra el impacto de las tasas de deforestación y la pérdida de bosques durante las últimas décadas utilizando datos combinados de Armenteras et al. (2017) y Pendrill y Persson (2017). Los países en rojo exhibieron altas tasas de deforestación y pérdida de bosques; en amarillo, tasas moderadas de deforestación o pérdida de bosques, y en blanco, bajas tasas de deforestación, menores pérdidas de bosques o datos no disponibles.

the Cerrado regions lost vegetation cover mostly for the agriculture expansion and the Amazonia has been cleared for pasturelands (Pendrill and Persson 2017).

Industrial intensification of agroforestry focuses on increasing crop yield through external inputs such as pesticides (see below), fertilizers, fuel and irrigation, which do not necessarily provide greater human nutrition quality or food sovereignty, but severely threaten biodiversity (e.g., Leguizamón 2014; Cáceres 2015; Pengue 2016). For example, the effects of agriculture expansion and intensification have been estimated for animal diversity in the Pampas of Argentina, showing that birds and carnivores were more strongly affected than rodents and insects (Medan et al. 2011). Moreover, conventional agroforestry tends to downgrade conditions for pollinators because it usually reduces habitat connectivity and decreases the availability of their floral and nesting resources (Landaverde-González et al. 2017). A side effect of massive habitat

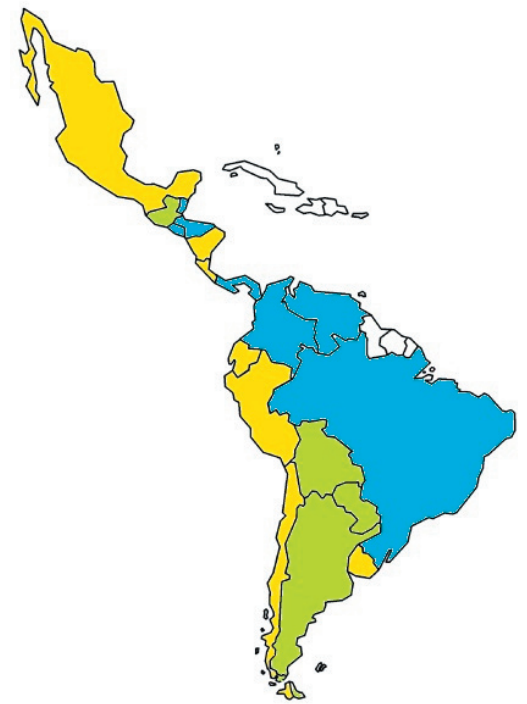

Figure 5. Map of Latin America showing the main drivers of deforestation using data from Pendrill and Persson (2017). Countries in green exhibited deforestation mostly due to agriculture expansion; in yellow, mostly due to expansion for cattle grazing; in blue, due to both main drivers; no data available to countries in white.

Figura 5. Mapa de América Latina que muestra los principales impulsores de la deforestación utilizando datos de Pendrill y Persson (2017). Los países en verde exhibieron deforestación principalmente debido a la expansión de la agricultura; en amarillo, principalmente debido a la expansión de tierras para el pastoreo de ganado; en azul, debido a estos dos impulsores principales; para los países en blanco no hay datos disponibles.

destruction driven by large-scale agriculture (e.g., soybean and sugarcane cultivation) is habitat homogenization (Leguizamón 2016), pollinator decline (Potts et al. 2016) and pollination deficits (Cruz-Neto et al. 2018).

Data for some regions regarding the consequences of land-use changes indicate that hummingbirds have declined due to habitat loss and fragmentation (Arizmendi et al. 2016). For example, $40 \%$ of the 58 hummingbird species present in México are classified as vulnerable or endangered, and some of them are endemic (Arizmendi et al. 2016). The same scenario was reported for nectarivorous bats, whose populations are also declining (Frick et al. 2019). Bats are functionally important since they play pivotal roles in various ecosystem services as seed dispersers and pollinators (Gonçalves et al. 2017). The diversity of hawkmoths and social bees has also shown negative trends at a local scale with the decline in regional forest cover (Ferreira et al. 2015). The reduction of habitat quality and landscape heterogeneity causes species loss and erodes functional diversity, 
thereby affecting plant-pollinator networks (Lopes et al. 2009; Ferreira et al. 2015).

\section{Risks caused by pesticide use}

Pesticide use is recognized as one of the main threats for pollinators due to both lethal and sublethal effects (IPBES 2016). There is a dramatically increase in pesticide application in South America between 1990 and 2018 $(>475 \%$ ) (FAO 2019) compared to Europe or North America (Figure 6). This phenomenon is particularly more impactful in those countries with huge areas of deforestation devoted to industrial monocultures (mostly soybean and maize) and cattle grazing (Figures 4 and 5), such as Brazil and Argentina (Figure

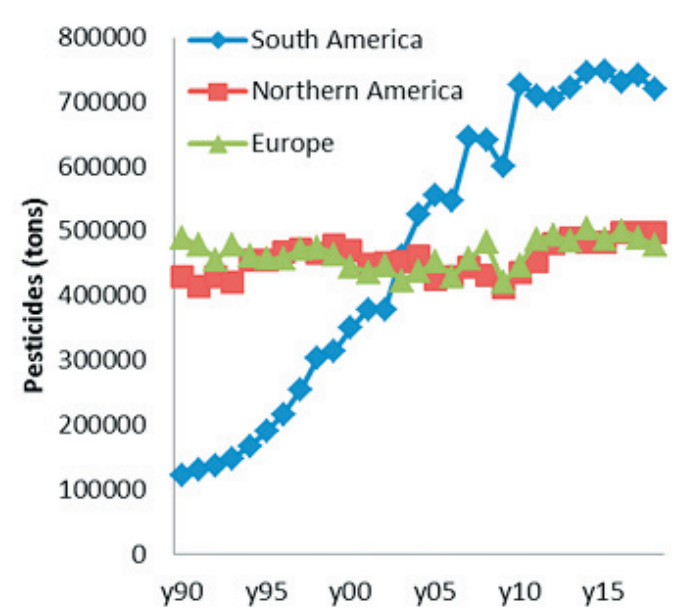

Figure 6. Annual pesticide applications (tons) during the period 1990-2018, comparing Europe, North and South America. Data source: www.fao.org/faostat/en/\#data/ $\mathrm{RP} /$ metadata.

Figura 6. Aplicaciones anuales de plaguicidas (toneladas) durante el período 1990-2018, comparando Europa, Norteamérica y Sudamérica. Fuente: www.fao.org/ faostat/en/\#data/RP/metadata.
7) with increases of 660 and $650 \%$ for this period 1990-2018, respectively (FAO 2019). Although other countries in this region, such as Bolivia, Paraguay and Uruguay, did not use annually the amounts of pesticides as Brazil and Argentina, they also showed an important change during the same period, with increases of 490,480 , and $870 \%$, respectively (Figure 8 ) (FAO 2019).

Agrochemicals can threaten pollinators, but the toxicity level depends on the concentration of the compounds, the species susceptibility and thelevel of exposureaccording to the spatial and temporal scale (Arena and Sgolastra 2014; Barbosa et al. 2015). A recent meta-analysis showed that stingless bees are more sensitive to various pesticides than honeybees (Arena and Sgolastra 2014). Riaño and Cure (2016) determined that the commercial formulations of three insecticides (imidacloprid, spinosad and thiocyclam hydrogen oxalate) are highly toxic for the workers of Bombus atratus, a neotropical species widely distributed in Colombia and considered an important pollinator of Andean agroecosystems. Nevertheless, most data are derived from laboratory studies with Apis mellifera, with comparatively less information on Bombus and stingless-bee species or on sublethal effects under field conditions and during large periods (Arena and Sgolastra 2014; Barbosa et al. 2015). Recently, some information on the effects of agrochemicals at environmentally relevant concentrations has been published for solitary bees (Graffigna et al. 2021; Mokkapati et al. 2021). For example, a field study in a Pampean agroecosystem (Argentina) showed that glyphosate influenced the behavior of the nesting females of wild solitary bees (Megachile spp.) and negatively affected their reproduction (Graffigna et al. 2021).

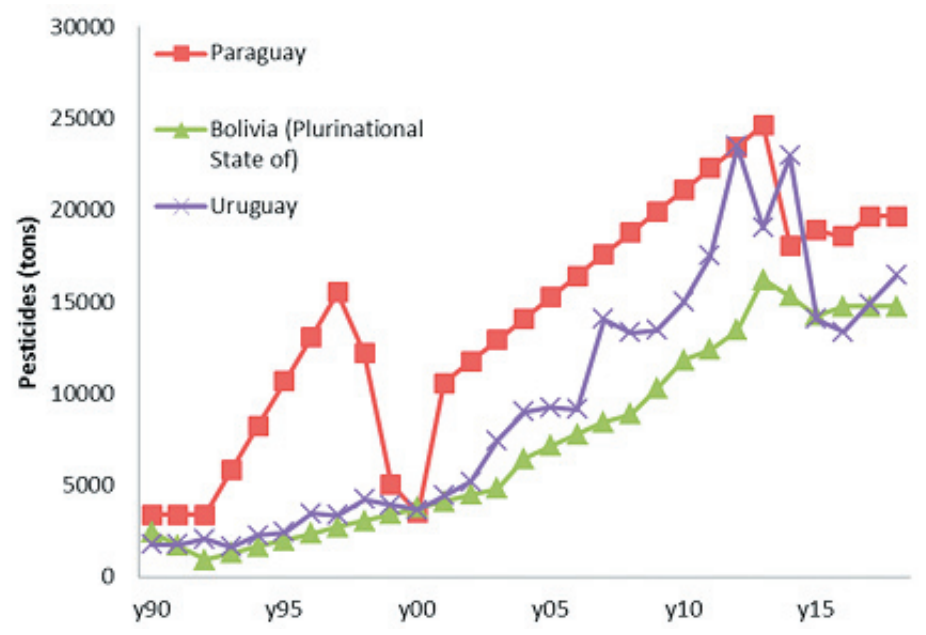

Figure 7. Annual pesticide applications (tons) during the period 1990-2018, comparing Paraguay, Bolivia and Uruguay. Data source: www.fao.org/ faostat/en/\#data/RP/metadata

Figura 7. Aplicaciones anuales de plaguicidas (toneladas) durante el período 1990-2018, comparando Paraguay, Bolivia y Uruguay. Fuente: www.fao.org/faostat/en/\#data/RP/ metadata. 


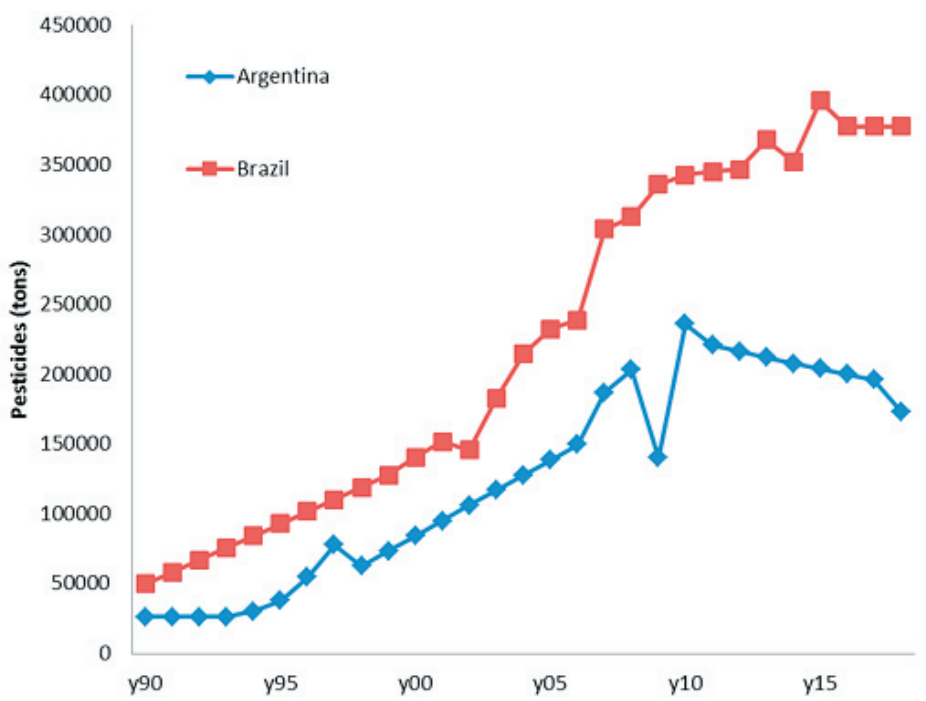

Figure 8. Annual pesticide applications (tons) during the period 1990-2018, comparing Brazil and Argentina. Data source: www.fao.org/faostat/en/\#data/ $\mathrm{RP} /$ metadata.

Figura 8. Aplicaciones anuales de plaguicidas (toneladas) durante el período 1990-2018, comparando Brasil y Argentina. Fuente: www.fao.org/ faostat/en/\#data/RP/metadata.
A review showed that $82 \%$ of the 216 studies addressing the direct impacts of insecticides on bees were performed in North America and Europe, with only 9\% performed in LA (Lundin et al. 2015; but see the review by Freitas and Pinheiro 2012). Neonicotinoids are the most widely used insecticides worldwide, and their sublethal effects on wild pollinator survival and reproduction under field conditions have now been demonstrated (Pisa et al. 2017), although their effects on managed colonies are still a matter of discussion. A pioneering study under field conditions showed strong sublethal effects, such as reductions in wild bee density, solitary-bee nesting and bumblebee colony growth and reproduction (Rundlöf et al. 2015). Moreover, neonicotinoids were found in $75 \%$ of the honey analyzed worldwide (including many samples from LA), demonstrating the exposure of honeybees to neonicotinoids in their food sources around the world (Mitchell et al. 2017). As a result of the high mortality of bee hives in Colombia, the Colombian Agricultural Institute (ICA) generated a resolution temporarily suspending all forms of production, commercialization and use of any agrochemical that in its composition contains Fipronil as an active ingredient in crops of avocado, coffee, citrus fruits and passion flowers (ICA 2021; resolution \#092101 of March 2021).

Herbicides are widely used to control weeds, but they also affect populations of native plants present in the agroecosystem (Ferreira et al. 2017). Thus, these compounds indirectly affect pollinators by reducing the number of available food sources or by increasing the abundance of resistant or tolerant flowering plants, the latter accumulating chemicals in nectar and pollen, which may affect pollinators (Rubio et al. 2014). In summary, neonicotinoids, herbicides and other pesticides are causing increasing harm to pollinators.

\section{Risks caused by genetically modified organisms (GMO)}

Genetically modified crops are herbicide tolerant (HT) or insect resistant (IR), and they can pose a threat to pollinators by having lethal or sub-lethal effects on adult insects or larvae (Nicodemo et al. 2018). A recent review on honeybees showed no clear negative effects of GMO on colony development (Ricroch et al. 2018). Supplements (i.e., nectar and pollen substitutes) containing GMO are used in apiculture to feed honeybees when flowers are scarce, and recent experimental studies have shown negative effects on bee health following the addition of a supplementary diet (for example, processed GMO corn) (Nicodemo et al. 2018). Moreover, bees visit GMO soybean flowers, and their pollen can be found in honey harvested by beekeepers (Villanueva-Gutiérrez et al. 2014).

The persistence of transgenes in nature was confirmed in South America, implying gene flow and introgression among feral populations of genetically modified Brassica napus and wild B. rapa mediated by pollinators (Pandolfo et al. 2018). More studies are needed to clarify the effects of genetically modified, HT and IR crops on pollinators, but the examples from LA indicate that the risks may depend on how GMO are spreading (whole 
plants, pollen, or genes) and on their presence among the resources accessed by pollinators.

\section{Risks caused by invasive species}

Greenhouse cultivation has notoriously increased across LA, creating a large demand for pollinating bees and the introduction of exotic species (Freitas et al. 2009), although traded exotic bumblebees (Bombus ruderatus and Bombus terrestris) have caused serious problems (Aizen et al. 2019). Chile has participated in the bumblebee trade, allowing the importation of these two alien bumblebee species for crop pollination, but then they invaded different biomes in Argentina (Schmid-Hempel et al. 2014; Aizen et al. 2019). It is well documented in LA that populations of alien pollinator species quickly spread across the landscape, with negative impacts on the abundance of native pollinator and the pollination of native plant species, besides causing the spread of invasive exotic plant species (e.g., Schmid-Hempel et al. 2014; Morales et al. 2017; Montalva et al. 2017).

In addition, populations of $B$. terrestris are infected with the protists trypanosomatid Crithidia bombi (Schmid-Hempel et al. 2014), the neogregarine Apicystis bombi and the microsporidium Nosema bombi (Plischuk et al. 2017). These multihost pathogens should be considered as potential threats to South American native Bombus dahlbomii (Plischuk et al. 2017). Bombus terrestris has been continuously introduced into Chile over the last 20 years $(>200000$ colonies and queens imported per year), showing that decisions in one country can have transnational negative effects on biodiversity (Aizen et al. 2019). For example, a large-scale investigation in Argentina showed that only 5 years after its arrival, $B$. terrestris had increased in population size, with the concurrent geographic retraction of the native B. dahlbomii (Morales et al. 2017). This well-documented South American case of bumblebee invasion should alert governments to the unintended consequences of bee trade (Aizen et al. 2019). For example, the introduction of the same species (native from LA) is not exempt from risks because a species may have populations that are genetically different in different regions. Recent attempts to introduce the managed $B$. atratus from Argentina to Colombia have led to molecular analysis of the respective populations, determining that those populations of $B$. atratus from Argentina and from Colombia are evolutionarily different (Lotta-Arévalo et al. 2021). In the same way, from studies of the genetic characterization of Bombus species in Colombia, great intraspecific genetic diversity was determined in two of the analyzed species (B. funebris, B. atratus) which may indicate the presence of different management units under the taxonomic level of the species. This information is of vital importance to formulate conservation strategies for these species in Colombia (Lotta-Arévalo et al. 2020).

\section{Risks caused by climate change}

There is ample evidence that climate change has exacerbated climate variability all over LA, with important environmental and socioeconomic consequences. Recent studies in LA have shown that climate influences pollinators (e.g., Giannini et al. 2017; FariasSilva and Freitas 2021), honey production (Koffler et al. 2015) and interactions between pollinators and plant species (Bezerra et al. 2019; Nemésio et al. 2016; Silva et al. 2019).

Climate change models in LA suggest potential reduction and shifts in the geographical distribution of crop pollinator bees. Preliminary losses of suitable areas of up to $35 \%$ were projected for bee pollinators of seven Brazilian crops (Giannini et al. 2012). Other study, considering bee pollinators of 13 crops, revealed the loss of pollinators and reductions from 9 to $100 \%$ in the probability of occurrence of these species (Giannini et al. 2017). Bees occurring in the eastern Brazilian Amazon, especially the crop-pollinators and the occurrence-restricted bees, potentially will be threatened by climate change, since results showed $95 \%$ of species will face a decline in their total occurrence area (Giannini et al. 2020). Other studies also showed that climate change can negatively affect the production of coffee (an assemblage of different bee species; Imbach et al. 2017), tomato (Bombus morio) (Elias et al. 2017) and passion fruit (Xylocopa spp.) (Giannini et al. 2013; Bezerra et al. 2019; Farias-Silva and Freitas 2021) due to potential loss of pollinators.

There are several other examples: orchid bee abundance will potentially be threatened in the Brazilian Atlantic Forest by climate change (Faleiro et al. 2018), or Bombus species of Mesoamerica will likely face a loss in their area of distribution ranging from $7 \%$ to $67 \%$ for the year 2050 (Martínez-López et al. 2021). Indeed, heat stress can occur in colonies of africanized honeybees managed 
in the tropics and subtropics. Heatwaves affect the thermoregulation ability of colonies (Poot-Baez et al. 2020), decreasing the immunocompetence of workers, queens and drones of Africanized honeybees (Medina et al. 2020). Stingless bees can also be forced to forage only in the cooler times of the day or to make shorter foraging trips, compromising their ability to survive in hotter environments (Maia-Silva et al. 2021).

Considering vertebrate species, the impact of climate change on nectarivorous bats in the eastern Brazilian Amazon also showed a potential average reduction of 20 to $30 \%$ in species suitable areas (Costa et al. 2018). Other study in the same region showed that nectarivorous birds can potentially lose up to $60 \%$ of their current projected diversity in the future scenarios (Miranda et al. 2019). Pollinator bat species were also analysed on México, indicating that $21 \%$ of their habitat will likely experience a loss of bat species richness (Zamora-Gutiérrez et al. 2021). Further research on the impact of climate change on pollinators on tropical areas of LA is increasingly urgent and will be instrumental in guiding policy decisions for conservation and restoration aiming to protect pollination services.

\section{KNOWLEDGE GAPS FOR THE CONSERVATION OF POLLINATORS}

We have identified many knowledge gaps regarding the status, trends and threats affecting native pollinators, beekeeping and eco-socio-environments (Table 1). Some of these gaps are related to the absence of basic information on pollinators and the pollination process in native and cultivated plants, but most of them show the importance of conducting research addressing the consequences of current anthropogenic threats on biodiversity conservation, along with alternatives related to TLK-based practices (Table 1). For example, a few risk-analysis studies have been performed on the impact of climate change on animal-pollinated crops at the regional scale (e.g., Imbach et al. 2017), showing the importance of conducting such studies to improve policy decisions for the conservation of pollinators and pollination services while also respecting different ethical views of ethnic minorities (Table 1 ).

Table 1. Knowledge gaps that reduce the opportunities for the conservation and better management of pollinators and pollination services in Latin America.

Tabla 1. Vacíos de conocimiento que disminuyen las oportunidades para una mejor gestión y la conservación de los polinizadores y los servicios de polinización en América Latina.

Status and trends

Status and trends

Status and trends

Threats and opportunities

Threats and opportunities

Threats and opportunities

Threats and opportunities

Trends and opportunities

Trends and opportunities
Most bee/insect collections kept in museums and private institutions are not digitalized, limiting knowledge regarding the patterns of species distribution and diversity

Few empirical data are available at a regional level to define critical thresholds for the pollination services provided by pollinators to many crops and most native plant species

Studies on traditional knowledge regarding pollinators and biocultural conservation are scarce for many regions in LA

Conventional intensive agriculture threatens pollinators and pollination, but alternative agricultural practices must be evaluated in terms of the linkages among crop yields, benefits to pollinators, habitat sustainability and human well-being

Pesticides affect pollinators, but data from field studies on many pollinator species and sublethal effects over the long term are not available

Anthropogenic threats are simultaneously acting to threaten pollinators and pollination services, but no studies are available to evaluate risks and define policies from this perspective

Long-term pollinator declines need to be modelled at large-scale levels considering different threats and basic data for different groups of pollinator

The continuous monitoring of exotic bumblebee and honeybee hives is required to prevent their future establishment and/or the spread of emerging diseases to native pollinators, such as stingless bee species

Local examples of indigenous peoples and local communities show that their practices are pollinator-friendly, but examples for different biomes at large scales are still lacking 
Although the balance between land-use cover to safeguard biodiversity (including pollinators) and land for agriculture represents a direct trade-off, the degree to which pollination contributes to sustainable crop yields has not been addressed when implementing agricultural policies (Table 1). Nevertheless, there are incipient programmes, laws and regulations regarding land-use management, biodiversity conservation and pesticide risk reduction that can benefit pollinators and pollination services. For example, the National Plan for Agro-Ecology and Organic Production (PLANAPO-Brazil, launched in 2013) was developed to coordinate policies and actions for environmentally friendly agriculture and organic food production. The forest law in Argentina (law \#26331 2007) is aimed at protecting native forests and their biodiversity. This law also considers the rights of campesinos and indigenous peoples living in these forests. At the same time, some pollinator initiatives have been developed to detect risks regarding the delivery of pollination services and associated opportunities (e.g., Brazil [Imperatriz-Fonseca et al. 2007], Colombia [Nates-Parra 2017]).

Many farming systems exist as alternatives to large-scale agriculture in LA, with differences in terms of ecological, social and economic performance. However, the socioeconomic performance of pollinator-friendly farming systems is poorly understood (Table 1) (Garibaldi et al. 2016). This knowledge gap hinders the efforts to improve agriculture's effect on all dimensions of people's livelihoods (Garibaldi et al. 2017), which can be improved considering TLK (Table 1) (Quezada-Euán et al. 2018; Hill et al. 2019). Land-use decisions oriented towards enhancing natural assets, such as pollinator-friendly farming systems, can also provide the highest levels of financial assets. For example, different initiatives designed to improve some cultivated crops in pollinator-friendly farming systems were successful in LA (e.g., coffee [Hipólito et al. 2016]). Furthermore, pollinator-friendly farming systems may provide multifunctional benefits to society, including those of recreational, cultural and health value (Garibaldi et al. 2017; Hill et al. 2019).

Although there are no coordinated, integrated initiatives to incorporate pollination services into national production systems in LA (Table 1), there are some related efforts, such as the summary of the role of pollination and its importance to sustainable agriculture in Chile,
Paraguay and Perú (FAO 2017). However, the design and implementation of management protocols for LA must be conducted bearing in mind not only the complexity of many of the ecological systems but also the socioeconomic particularities of many of the countries, including high poverty, cyclic economic crises, and political unrest.

Improving scientific education enhances the opportunities to conserve biodiversity and ecosystem services mostly if it causes a change in the dominant models of agricultural and social consumption patterns. Methodologies that can integrate not only disciplines but also social and legal frameworks promoting the conservation and management of pollinators through a holistic agro-ecological view (Table 1) will produce robust results to support human well-being and better decision making at different spatial and temporal scales. Given the complexity and uncertainties of LA's socio-ecological systems, the effectiveness of any educational programme regarding pollinators and the conservation of pollinator services must go beyond the view of a single discipline, requiring inter- and transdisciplinary approaches involving multi-stakeholders. Currently, the internet and social media are the most popular outreach tools. In LA, several blogs on pollinators and pollination services exist (e.g., Comunidad de Polinización [fao.org] and Associação Brasileira de Estudos das Abelhas [abelha.org.br]). Participatory mechanisms are valuable tools to engage people in ways that may modify their behaviour, providing environmental, social and economic benefits to their community. Civil society is perhaps the sector that needs the greatest support to understand the importance of the conservation and management of pollinators. For example, in some regions of LA, citizen-science initiatives successfully involve civil society to obtain national data to register flowervisitor interactions (guardioes.cria.org.br), to take care of native pollinators and to evaluate invasion risks (Montalva et al. 2017). These examples show that it is possible to integrate scientific knowledge, TLK and civil society in conservation initiatives for native pollinators.

\section{Recommendations to CONSERVE POLLINATORS AND POLLINATION SERVICES}

We present some recommendations that may be considered by stakeholders and 
governments to conserve native pollinators and improve pollination services (Table 2 ). These points are focused on Latin American reality and complexity, and are complementary to those proposed at a global level (Dicks et al. 2016, 2021; Hill et al. 2019). Nevertheless, we think the consideration of the status of pollinators and the threats affecting pollination and the food production system in LA may lead to improved biodiversity conservation in many other developing tropical and subtropical countries. These suggestions were generated considering their applicability at different scales, but they need to be supported by common policies across different countries sharing mega-diverse biomes.

Diverse threats are interlinked with pollinators, and pollination decline affects

Table 2. Recommendations for improving pollinator conservation, pollination services and human well-being in Latin America.

Tabla 2. Recomendaciones para mejorar la conservación de los polinizadores, los servicios de polinización y el buen vivir en América Latina.

Problem
Many pollinators need to be described,
or their natural history is partially or
completely unknown
Long-term, large-scale monitoring studies
of pollinators and pollination services are
not available

Anthropogenic threats, mainly deforestation, are threatening biodiversity

Pollinators and pollination services are declining in many regions of LA, but few empirical data are available

Yield reduction is occurring in pollinatordependent crops

Conventional agriculture, with high inputs of insecticides and herbicides, threatens pollinators

Many colonies of honeybees and stingless bees are lost every year

Pathogens and parasites are widespread among managed bee colonies and affect their health status

GMO crops dominate most agroecological landscapes in the region, but little is known about the consequences for pollinators

Policies and legal regulations on managed pollinators should be better coordinated in the region. The public is not aware on the importance of pollinators and pollination for human well-being

Each country in the region makes unilateral decisions on bee trade, favouring transnational bee invasions
Suggested solution for policy options

Support for basic scientific projects to increase the taxonomic knowledge regarding pollinators is important for pollinator conservation

Long-term studies that use transdisciplinary approaches, such as citizen science, and consider different threats related to pollinator and pollination decline are important to be supported and maintained. Baseline studies should be performed at the local and regional levels to evaluate declines in wild bee species and other pollinator groups

The conservation of natural habitats and creation of corridors between crop fields and the diversification of production systems should be encouraged to conserve biodiversity and ecosystem services, including pollinators and pollination

Habitat friendly designs at landscape and local levels need to be promoted for increase both populations of pollinators and crop pollination, but also pollination of native plants. Artificial nests can be added in semi-natural habitats to improve reproduction of wild solitary bee species and other pollinators

Small-scale traditionally diversified farming systems, which are already present in most regions of LA, are beneficial to native pollinators and should be supported to maintain yields of many crops

The exposure of pollinators to pesticides should be minimized through small changes in the current practices (for example, avoiding spraying early in the morning or reducing doses to a minimum level, etc.), but also improving regulations, policies and legal responses for supporting agroecological practices with alternative pest control systems

The scientific knowledge on the threats for managed bees need to de increased and the continuous evaluation by beekeepers of the adequate densities of managed colonies and the relative availability of resources for pollinators (i.e., native species and flowering crops) are necessary to improve the management of pollination services, increase honey production and conserve biodiversity

The health of managed pollinators in LA should be improved; this will lead to more sustainable conditions (higher floral diversity, fewer pesticides, lower deforestation and agricultural intensification, etc.) for the native pollinators and managed bees. Moving honeybee colonies over long distances must be minimized because it could lead to pathogen spill over to native species, such as bumblebees

Studies regarding the risks of GMO spread (whole plants or pollen) in pollen or nectar and on the consequences for species of pollinators should be conducted

Coordinated collaborative actions are necessary to conserve native pollinators and pollination services for many important crops and most native species, such as combining policies and legal responses at the regional level, raising public awareness and ecological literacy and improving scientific research over the long term

Coordinated decisions on species importation permits and regional surveillance systems are needed to prevent and halt alien bee invasions 
the reproduction of many native plants and crop yields. For example, deforestation, conventional agriculture and the associated overuse of agrochemicals and the introduction of exotic species are becoming serious threats to native pollinators and managed bees in LA. However, some policies promoting habitat friendly designs at landscape and local levels are needed for increase both populations of pollinators and crop pollination (Table 2). At the same time, artificial nests (called "bee hotels") can be added in semi-natural habitats to improve reproduction mostly of wild solitary bee species, but also of other pollinators (Bortolotti et al. 2016; Rahimi et al. 2021). Moreover, studies addressing multiple threats are scant, and their combined effects on biodiversity decline and pollination deficits are unknown (Table 2). For example, studies addressing complex land use changes due to industrial agriculture on pollinators and pollinations deficits for crops and native plants are not available, because they imply detailed knowledge on the effects of application of large amounts of agrochemicals, on the lethal and sublethal effects on pollinators during long periods, on the consequences of the reduction of the populations of native plants because they are used by pollinators for their nourishments and nesting, on the implications of the increases of the populations of exotic resistant weeds, among other ecological processes. Management strategies for improving food production systems and conservation practices addressing pollinators declines must integrate proper actions that consider both local and regional scales and socioeconomic realities. For existing fragmented landscapes, it is important to increase natural habitats for pollinators at the regional scale while also maintaining high habitat heterogeneity at the local scale.

Current policies and legal frameworks in LA were thought to increase crop and cattle production via deforestation for lands devoted to large-scale agriculture and cattle grazing, but these changes in land uses increased the risks to biodiversity through different threats. Benefits for pollinators can be achieved if sustainable management of agriculture is promoted (Table 2). For example, ecological intensification, diversified farming systems and the increase of ecological infrastructure have been recently suggested to improve conditions for pollinators and the pollination of some crops and wild plants (Dicks et al. 2016; Garibaldi et al. 2017). These alternative approaches for agroecological agriculture may also provide opportunities to local and indigenous communities to maintain their knowledge systems and practices in natural habitats as well as in small to medium-sized crop stands. For example, three alternative approaches for agriculture were suggested by Hill et al. (2019). They incorporate the socioeconomic dimensions of local communities to improve food sovereignty, enhancing ecosystem services (such as pollination services) and having mutual benefits for pollinators and local people.

Intensive long-term investment by stakeholders is necessary to support and create incentives for the development of pollinator-friendly farming systems that allow biodiversity conservation (Table 2). Policies regarding crop pollination practices need to consider the benefits to society (Garibaldi et al. 2017) and to compensate farmers for those benefits if sustainable management practices are to be effectively implemented. Examples include introducing incentives to help farmers maintain natural habitats and forests, to replace or reduce agrochemicals and to improve diversified crop production. Complementary policy options could refine agrochemical regulations to minimize the exposure of pollinators to insecticides and herbicides (Table 2). New practices can be developed via public education (e.g., avoiding spraying pesticides early in the morning or reducing doses to a minimum level) (IPBES 2016; Dicks et al. 2016) or through alternative modes of agroforestry or pest control considering TLK (Hill et al. 2019). These policies will also require social, political, and legal agreements across countries to implement these specific and general recommendations at a continental scale.

In parallel, it is necessary to adopt public policies that ensure the regularity of scientific research incorporating multiple practices and recognizing that TLK can enhance or complement scientific knowledge to conserve biodiversity (IPBES 2016; Quezada-Euán et al. 2018). This wider view assesses multiple dimensions (social, ecological, cultural, etc.), integrates the pollinator species and habitat management approaches within environmentally friendly farming systems, and evaluates the value of pollinators beyond crop pollination, filling important knowledge gaps in this area. Scientific knowledge plays a fundamental role in contemporary society 
and has influenced the development of policies in several areas. For example, reliable biodiversity baselines will be obtained through regular public policies to ensure the funding of trans-disciplinary scientific research and public education over the long term (Table 2 ). This basis may allow for successful conservation planning and the evaluation of pollinator responses to multiple threats.

The general strategy for the mitigation of pollinator declines in LA involves an increase in technical responses that are unevenly scattered across different countries. It is clear that LA lacks effective legal and economic instruments to conserve pollinators and pollination services, indicating the need to develop integrated programmes at a regional level that can be widely adopted by national governments and multi-lateral agencies (Table 2).

\section{Conclusions}

In this review, we identified many threats associated with pollinator and pollination decline and subsequent risks to human wellbeing. It is true that large-scale agroforestry is the main threat to biodiversity in developing countries, but we have presented some ideas to both increase sustainable production and conserve biodiversity. Latin America sustains a rich variety of cultures and many millions of people living under the economic line of poverty that are affected by the discussed threats, making it necessary to identify a more sustainable and socially fair transition pathway out of the current production model based on commodities. It is necessary to acknowledge the socio-environmental complexity of food production systems if we want to better understand the impacts of different agricultural threats on pollinators and pollination. In addition, it is very important to consider the ways in which we can support TLK and its practices to preserve and manage biodiversity and to develop sustainable agroforestry.

Understanding the relationship between science and policy, especially in the environmental area, is still a challenge to overcome, since much scientific knowledge has not been translated into policies and guidelines for the conservation of natural resources, particularly for those that are under serious threats. Legal responses can drive on-the-ground changes, but they are not in themselves a change to the natural environment in which pollination occurs. We need creativity and urgent actions to conserve pollinators and pollination services in LA.

The consideration of our recommendations may lead to improve biodiversity conservation in many other developing tropical and subtropical countries. These suggestions were generated considering their applicability at different scales across different countries sharing mega-diverse biomes, but they need to be supported by common socio-environmental policies to be effective in the sustainable development and consequently in the use of the ecosystem services provided by such great biocultural diversity.

Acknowledgements. We thank three anonymous reviewers for their useful comments and suggestions. We would like to warmly thank IPBES for having dedicated its first assessment report to the important issue of pollinators and for having brought an unprecedented level of awareness on their importance and loss worldwide. In consequence, we thank IPBES colleagues for many discussions during the writing of the IPBES pollination assessment, although here we are focused on Latin America reality. Thus, the views expressed here represent the perspectives of the authors of this article.

\section{REFERENCES}

Achard, F., H. D. Eva, H. J. Stibig, P. Mayaux, J. Gallego, T. Richards, and J. P. Malingreau. 2002. Determination of deforestation rates of the world's humid tropical forests. Science 80(297):999-1002. https://doi.org/10.1126/ science.1070656.

Aizen, M. A., C. SmithRamírez, C. L. Morales, L. Vieli, A. Sáez, R. M. BarahonaSegovia, M. P. Arbetman, J. Montalva, L. A. Garibaldi, D. W. Inouye, and L. D. Harder. 2019. Coordinated species importation policies are needed to reduce serious invasions globally: The case of alien bumblebees in South America. Journal of Applied Ecology 56(1):100-106. https://doi.org/10.1111/1365-2664.13121.

Arena, M., and F. Sgolastra. 2014. A meta-analysis comparing the sensitivity of bees to pesticides. Ecotoxicology 23: 324-334. https://doi.org/10.1007/s10646-014-1190-1.

Arizmendi, M. D. C., H. Berlanga, C. Rodríguez-Flores, V. Vargas-Canales, L. Montes-Leyva, and R. Lira. 2016. Hummingbird conservation in México: the natural protected areas system. Natural Areas Journal 36(4):366-376. https://doi.org/10.3375/043.036.0404. 
Armenteras, D., J. M. Espelta, N. Rodríguez, and J. Retana. 2017. Deforestation dynamics and drivers in different forest types in Latin America: Three decades of studies (1980-2010). Global Environmental Change 46:139-147. https: //doi.org/10.1016/j.gloenvcha.2017.09.002.

Avila Jr., R. S., R. Oliveira, C. E. Pinto, F. W. Amorin, and C. Schlindwein. 2012. Relações entre esfingídeos (Lepidoptera, Sphingidae) e flores no Brasil: panorama e perspectivas de uso de polinizadores. En V. L. Imperatriz-Fonseca (ed.). Polinizadores no Brasil. EdUSP. São Paulo, Brasil.

Barbosa, W. F., G. Smagghe, and R. N. C. Guedes. 2015. Pesticides and reducedrisk insecticides, native bees and pantropical stingless bees: pitfalls and perspectives. Pest Management Science 71:1049-1053. https://doi.org/10.1002/ ps.4025.

Bezerra, A. D. M., A. S. J. Pacheco Filho, I. G. A. Bomfim, G. Smagghe, and B. M. Freitas. 2019. Agricultural area losses and pollinator mismatch due to climate changes endanger passion fruit production in the Neotropics. Agricultural Systems 169:49-57. https://doi.org/10.1016/j.agsy.2018.12.002.

Bezerra, L. A., A. J. Campbell, T. F. Brito, C. Menezes, and M. M. Maués.2020. Pollen loads of flower visitors to Açaí Palm (Euterpe oleracea) and implications for management of pollination services. Neotropical Entomology 1:1-9. https: //doi.org/10.1007/s13744-020-00790-x.

Blanckaert, I., K. Vancraeynest, R. L. Swennen, F. J. Espinosa-García, D. Pinero, and R. Lira-Saade. 2007. Non-crop resources and the role of indigenous knowledge in semi-arid production of México. Agriculture, Ecosystems and Environment 119:39-48. https://doi.org/10.1016/j.agee.2006.06.015.

Bomfim, I. G. A., A. D. M. Bezerra, A. C. Nunes, F. A. S. Aragão, and B. M. Freitas. 2014. Adaptive and foraging behavior of two stingless bee species (Apidae: Meliponini) in greenhouse mini watermelon pollination. Sociobiology 61:502-509.

Bomfim, I. G. A., B. M. Freitas, F. A. S. Aragão, and S. A. Walters. 2016. Pollination in cucurbit crops. In M. Pessarakli (ed.). Handbook of Cucurbits: Growth, Cultural Practices, and Physiology. CRC Press, Boca Raton, USA.

Bortolotti, L., G. Bogo, N. de Manincor, A. Fisogni, and M. Galloni. 2016. Integrated conservation of bee pollinators of a rare plant in a protected area near Bologna, Italy. Conservation Evidence 13:51-56.

Buchmann, S. E., and G. P. Nabhan. 1996. The Forgotten Pollinators. Island Press, Washington, DC, USA.

Buzato, S., T. C. Giannini, I. C. Machado, M. Sazima, and I. Sazima. 2012. Polinizadores vertebrados: uma visão geral para as espécies brasileiras. Pp. 119-141 in V. L. Imperatriz Fonseca, D. A. Lange Canhos, D. de Araujo Alves, and A. M. Saraiva (eds.). Polinizadores no Brasil: contribuição e perspectivas para a biodiversidade, uso sustentável, conservação e serviços ambientais. EdUSP, São Paulo, Brasil.

Cáceres, D. M. 2015. Accumulation by Dispossession and SocioEnvironmental Conflicts Caused by the Expansion of Agribusiness in Argentina. Journal of Agrarian Change 15(1):116-147. https://doi.org/10.1111/joac.12057.

Calle, Z., M. Guariguatá, E. Giraldo, and J. Chará. 2010. La producción de maracuyá (Passiflora edulis) en Colombia: perspectivas para la conservación de hábitat a través del servicio de polinización. Interciencia 35(3):207-212.

de Camargo, A. J. A., W. R. F. de Camargo, D. Corrêa, M. D. F. Vilela, and F. W. Amorim. 2018. Mariposas polinizadoras do cerrado: identificação, distribuição, importância e conservação. Embrapa Cerrados-Livro técnico (INFOTECA-E), Brasil.

Camillo, E. 2003. Polinizaçao do maracuja. Holos Editora, Ribeirao Preto, SP, Brasil.

Campbell, A. J., L. G. Carvalheiro, M. M. Maués, R. Jaffé, T. C. Giannini, M. A. B. Freitas, B. W. T. Coelho, and C. Menezes. 2018. Anthropogenic disturbance of tropical forests threatens pollination services to açaí palm in the Amazon river delta. Journal of Applied Ecology 55:1725-1736. https://doi.org/10.1111/1365-2664.13086.

Carvalho, R. M. A., C. F. Martins, and J. da Silva Mourão. 2014. Meliponiculture in Quilombola communities of Ipiranga and Gurugi, Paraíba state, Brazil: an ethnoecological approach. Journal of Ethnobiology and Ethnomedicine 10:3. https://doi.org/10.1186/1746-4269-10-3.

Cavalcante, M. C., L. Galetto, M. M. Maués, A. L. S. Pacheco Filho, I. S. A. Bomfim, and B. M. Freitas. 2018. Nectar production dynamics and daily pattern of pollinators visits in Brazil nut (Bertholletia excelsa Bonpl.) plantations in Central Amazon: implications for fruit production. Apidologie 49:505-516. https://doi.org/10.1007/s13592-018-0578y.

Chacoff, N. P., and M.A. Aizen. 2006. Edgeeffects on flower-visiting insects in grapefruit plantations bordering premontane subtropical forest. Journal of Applied Ecology 43:18-27. https://doi.org/10.1111/j.1365-2664.2005.01116.x.

Costa, W. F., M. Ribeiro, A. M. Saraiva, V. L. Imperatriz-Fonseca, and T. C. Giannini. 2018. Bat diversity in Carajás National Forest (Eastern Amazon) and potential impacts on ecosystem services under climate change. Biological Conservation 218:200-210. https://doi.org/10.1016/j.biocon.2017.12.034.

Cruz-Neto, O. C., J. L. S. Silva, M. M. Woolley, M. Tabarelli, and A. V. Lopes. 2018. Pollination partial recovery across monospecific plantations of a native tree (Inga vera, Leguminosae) in the Atlantic forest: Lessons for restoration. Forest Ecology and Management 427:383-391. https://doi.org/10.1016/j.foreco.2018.06.023.

Dicks, L. V., B. F. Viana, R. Bommarco, B. Brosi, M. C. Arizmendi, S. A. Cunningham, L. Galetto, R. Hill, A. V. Lopes, C. Pires, H. Taki, and S. G. Potts. 2016. Ten policies for pollinators. Science 354 (6315):975-976. https://doi.org/10.1126/ science.aai9226.

Dicks, L. V., T. D. Breeze, H. T. Ngo, D. Senapathi, J. An, M. A. Aizen, P. Basu, D. Buchori, L. Galetto, L. A. Garibaldi, B. Gemmill-Herren, B. G. Howlett, V. L. Imperatriz-Fonseca, S. D. Johnson, A. Kovács-Hostyánszki, Y. J. Kwon, H. M. G. Lattorff, T. Lungharwo, C. L. Seymou, A. J. Vanbergen, and S. G. Potts. 2021. A global-scale expert assessment of drivers and risks associated with pollinator decline. Nature Ecology and Evolution 5(10):1453-1461. https://doi.org/ 10.1038/s41559-021-01534-9. 
Diemont, S. A., J. L. Bohn, D. D. Rayome, S. J. Kelsen, and K. Cheng. 2011. Comparisons of Mayan Forest management, restoration, and conservation. Forest Ecology and Management 261:1696-1705. https://doi.org/10.1016/ j.foreco.2010.11.006

Dos Santos, C. F., A. Otesbelgue, and B. Blochtein. 2018. The dilemma of agricultural pollination in Brazil: Beekeeping growth and insecticide use. PLoS One 13(7):e0200286. https://doi.org/10.1371/journal.pone.0200286.

Costa, W. F., M. Ribeiro, A. M. Saraiva, V. L. Imperatriz-Fonseca, and T. C. Giannini. 2018. Bat diversity in Carajás National Forest (Eastern Amazon) and potential impacts on ecosystem services under climate change. Biological Conservation 218: 200-210. https://doi.org/10.1016/j.biocon.2017.12.034.

Echavarriìa, R. J., O. A. Jimeìnez, M. L. Palacios, and M. J. Rengifo. 2018. Diversidad y composicioìn de murcieìlagos (Mammalia: Chiroptera) en el municipio de Acandiì, Chocoì - Colombia. Revista Colombiana de Ciencias Animales 10(1):7-14. https://doi.org/10.24188/recia.v10.n1.2018.628.

Eilers, E. J., C. Kremen, S. Smith Greenleaf, A. K. Garber, and A-M. Klein. 2011. Contribution of pollinator-mediated crops to nutrients in the human food supply. PLoS ONE 6(6):e21363. https://doi.org/10.1371/journal.pone.0021363.

Elias, M. A. S., F. J. A. Borges, L. L. Bergamini, E. V. Franceschinelli, and E. R. Sujii. 2017. Climate change threatens pollination services in tomato crops in Brazil. Agriculture, Ecosystems and Environment 239:257-264. https://doi.org/ 10.1016/j.agee.2017.01.026.

Falcheti, A. M., and G. Nates Parra. 2002. Las hijas del sol: las abejas sin aguijón en el mundo U'wa, Sierra Nevada del Cocuy. In Ulloa A. Editor. Rostros culturales de la fauna. Instituto Colombiano de Antropología e Historia y Fundación Natura. Pp. 175-214.

Faleiro, F. V., A. Nemésio, and R. Loyola. 2018. Climate change likely to reduce orchid bee abundance even in climatic suitable sites. Global Change Biology 24(6):2272-2283. https://doi.org/10.1111/gcb.14112.

FAO. 2017. Estado del Arte del Servicio Ecosistémico de la Polinización en Chile, Paraguay y Perú. Organización de las Naciones Unidas para la alimentación y la agricultura. Santiago de Chile, Chile.

FAOSTAT. 2017. URL: fao.org/faostat/en/\#data/QC.

FAO. 2019. Pesticide use data. URL: fao.org/faostat/en/\#data/RP/metadata.

Farias-Silva, F. J., and B. M. Freitas. 2021. Thermoregulation in the large carpenter bee Xylocopa frontalis in the face of climate change in the Neotropics. Apidologie 52(2):341-357. https://doi.org/10.1007/s13592-020-00824-8.

Fehlenberg, V., M. Baumann, N. I. Gasparri, M. Piquer-Rodríguez, G. Gavier-Pizarro, and T. Kuemmerle. 2017. The role of soybean production as an underlying driver of deforestation in the South American Chaco. Global Environmental Change 45:24-34. https://doi.org/10.1016/j.gloenvcha.2017.05.001.

Ferreira, F. M., C. Torres, E. Bracamonte, and L. Galetto. 2017. Effects of the herbicide glyphosate on non-target plant native species from Chaco Forest (Argentina). Ecotoxicology and Environmental Safety 144:360-368. https://doi.org/ 10.1016/j.ecoenv.2017.06.049.

Ferreira, P. A., D. Boscolo, L. G. Carvalheiro, J. C. Biesmeijer, P. L. Rocha, and B. F. Viana. 2015. Responses of bees to habitat loss in fragmented landscapes of Brazilian Atlantic Rainforest. Landscape Ecology 30:2067-2078. https: //doi.org/10.1007/s10980-015-0231-3.

Freitas, B.M., V. L. Imperatriz-Fonseca, L. M. Medina, A. M. P. Kleinert, L. Galetto, G. Nates-Parra, and J. J. G. Quezada-Euán. 2009. Diversity, threats and conservation of native bees in the Neotropics. Apidologie 40:332-346. https://doi.org/10.1051/apido/2009012.

Freitas, B. M., and J. N. Pinheiro. 2012. Polinizadores e pesticidas: principios de manejo para os ecossistemas brasileiros. MMA, Brasília, Brasil.

Frick, W. F., T. Kingston, and J. Flanders. 2019. A review of the major threats and challenges to global bat conservation. Annals of the New York Academy of Sciences 1469(1):5-25. https://doi.org/10.1111/nyas.14045.

Fuster, F., C. KaiserBunbury, J. M. Olesen, and A. Traveset. 2019. Global patterns of the double mutualism phenomenon. Ecography 42(4):826-835. https://doi.org/10.1111/ecog.04008.

Galetto, L., L. A. Garibaldi, and M. A. Aizen. 2018. El valor de los polinizadores. Investigación y Ciencia (Barcelona, España) 503:34-40.

Galetto, L., C. Torres, and G. Martínez Pastur. 2019. Variable retention harvesting: conceptual analysis according to different environmental ethics and forest valuation. Ecological Processes 8:40. https://doi.org/10.1186/s13717-019 0195-3.

Garibaldi, L. A., M. B. Dondo, J. Hipólito, N. Azzu, B. F. Viana, and M. Kasina. 2016. A quantitative approach to the socio-economic valuation of pollinator-friendly practices: a protocol for its use. Food and Agriculture Organization of the United Nations, Rome, Italy.

Garibaldi, L. A., B. Gemmill-Herren, R. D’Annolfo, B. E. Graeub, S. A. Cunningham, and T. D. Breeze. 2017. Farming approaches for greater biodiversity, livelihoods, and food security. Trends in Ecology and Evolution 32:68-80. https: //doi.org/10.1016/j.tree.2016.10.001.

Geslin, B., M. A. Aizen, N. García, A. J. Pereira, V. E. Vaissière, and L. A. Garibaldi. 2017. The impact of honey bee colony quality on crop yield and farmers' profit in apples and pears. Agriculture, Ecosystems and Environment 248: 153-161. https://doi.org/10.1016/j.agee.2017.07.035.

Ghosh, S., and C. Jung. 2018. Contribution of insect pollination to nutritional security of minerals and vitamins in Korea. Journal of Asia-Pacific Entomology 21(2):598-602. https://doi.org/10.1016/j.aspen.2018.03.014.

Giannini, T. C., A. L. Acosta, C. A. Garófalo, A. M. Saraiva, I. Alves-dos-Santos, and V. L. Imperatriz-Fonseca. 2012. Pollination services at risk: bee habitats will decrease owing to climate change in Brazil. Ecological Modelling 244: 
127-131. https://doi.org/10.1016/j.ecolmodel.2012.06.035.

Giannini, T. C., A. L. Acosta, C. I. da Silva, P. E. A. M. de Oliveira, V. L. Imperatriz-Fonseca, and A. M. Saraiva. 2013. Identifying the areas to preserve passion fruit pollination service in Brazilian Tropical Savannas under climate change. Agriculture, Ecosystems and Environment 171:39-46. https://doi.org/10.1016/j.agee.2013.03.003.

Giannini, T. C., G. D. Cordeiro, B. M. Freitas, A. M. Saraiva, and V. L. Imperatriz-Fonseca. 2015. The dependence of crops for pollinators and the economic value of pollination in Brazil. Journal of Economic Entomology 108:849-857. https://doi.org/10.1093/jee/tov093.

Giannini, T. C., W. F. Costa, G. D. Cordeiro, V. L. Imperatriz-Fonseca, A. M. Saraiva, J. Biesmeijer, L. A. Garibaldi. 2017. Projected climate change threatens pollinators and crop production in Brazil. Plos One 12:e0182274.

Giannini, T. C., W. F. Costa, R. C. Borges, L. Miranda, C. P. W. da Costa, A. M. Saraiva, A. M., and V. L. ImperatrizFonseca. 2020. Climate change in the Eastern Amazon: crop-pollinator and occurrence-restricted bees are potentially more affected. Regional Environmental Change 20(1):1-12. https://doi.org/10.1007/s10113-020-01611-y.

Gonçalves, F., E. Fischer, and R. Dirzo. 2017. Forest conversion to cattle ranching differentially affects taxonomic and functional groups of Neotropical bats. Biological Conservation 210:343-348. https://doi.org/10.1016/ j.biocon.2017.04.021.

Graffigna, S., H. J. Marrero, and J. P. Torretta. 2021. Glyphosate commercial formulation negatively affects the reproductive success of solitary wild bees in a Pampean agroecosystem. Apidologie 52(1):272-281. https://doi.org/ 10.1007/s13592-020-00816-8.

Grez, A., and L. Galetto. 2011. Fragmentación del paisaje en América Latina: ¿en qué estamos? Pp. 63-78 en J. A. Simonetti and R. Dirzo (eds.). Conservación biológica: perspectivas desde América Latina. Editorial Universitaria, Santiago de Chile, Chile.

Harvey, D. 2003: The new imperialism. Oxford University Press, Oxford. https://doi.org/10.1093/oso/ 9780199264315.001.0001.

Hill, R., G. Nates-Parra, J. J. G. Quezada-Euán, D. Buchori, G. LeBuhn, M. M. Maués, P. L. Pert, P. K. Kwapong, S. Saeed, S. J. Breslow, M. Carneiro da Cunha, L. V. Dicks, L. Galetto, M. Gikungu, B. G. Howlett, V. L. Imperatriz-Fonseca, P. O. Lyver, B. Martín-López, E. Oteros-Roza, S. G. Potts, and M. Roué. 2019. Biocultural approaches to pollinator conservation. Nature Sustainability 2:214-222. https://doi.org/10.1038/s41893-019-0244-z.

Hipólito, J., D. Boscolo, and B. F. Viana. 2018. Landscape and crop management strategies to conserve pollination services and increase yields in tropical coffee farms. Agriculture Ecosystems and Environment 256:218-225. https: //doi.org/10.1016/j.agee.2017.09.038.

Hipólito, J., B. F. Viana, and L. A. Garibaldi. 2016. The value of pollinator-friendly practices: Synergies between natural and anthropogenic assets. Basic and Applied Ecology 17:659-667. https://doi.org/10.1016/j.baae.2016.09.003.

Huais, P. Y., G. Grilli, L. D. Amarilla, C. Torres, L. Fernández, and L. Galetto. 2020. Forest fragments influence pollination and yield of soybean crops in Chaco landscapes. Basic and Applied Ecology 48:61-72. https://doi.org/ 10.1016/j.baae.2020.09.003.

Imbach, P., E. Fung, L. Hannah, C. E. Navarro-Racines, D. W. Roubik, T. H. Ricketts, C. A. Harvey, C. I. Donatti, P. Läderach, B. Locatelli, and P. R. Roehrdanz. 2017. Coupling of pollination services and coffee suitability under climate change. Proceedings of the National Academy of Sciences 114(39):10438-10442. https://doi.org/10.1073/ pnas.1617940114.

Imperatriz-Fonseca, V. L., A. M. Saraiva, and L. S. Gonçalves. 2007. A iniciativa brasileira de polinizadores e os avanços atuais para a compreensão do papel dos polinizadores como produtores de serviços ambientais. Bioscience Journal 23:100-106.

ICA. 2021. Instituto Colombiano de Agricultura. Resolution \#092101 of March 2021. URL: tinyurl.com/y8h4ckpt.

IPBES. 2016. The assessment report of the Intergovernmental Science-Policy Platform on Biodiversity and Ecosystem Services on pollinators, pollination and food production. In S. G. Potts, V. L. Imperatriz-Fonseca and H. T. Ngo (eds.). Secretariat of the Intergovernmental Science-Policy Platform on Biodiversity and Ecosystem Services, Bonn, Germany.

Jaffé, R., N. Pope, A. L. Acosta, D. A. Alves, M. C. Arias, P. De la Rúa, F. O. Francisco, T. C. Giannini, A. GonzálezChaves, V. L. Imperatriz-Fonseca, M. G. Tavares, S. Jha, and L. G. Carvalheiro. 2016. Beekeeping practices and geographic distance, not land use, drive gene flow across tropical bees. Molecular Ecology 25(21):5345-5358. https: //doi.org/10.1111/mec.13852.

Jenkins, C. N., S. L. Pimm, and L. N. Joppa. 2013. Global patterns of terrestrial vertebrate diversity and conservation. Proceedings of the National Academy of Sciences 110(28):E2602-E2610. https://doi.org/10.1073/pnas.1302251110.

Kier, G., J. Mutke, E. Dinerstein, T. H. Ricketts, W. Küper, H. Kreft, and W. Barthlott. 2005. Global patterns of plant diversity and floristic knowledge. Journal of Biogeography 32(7):1107-1116. https://doi.org/10.1111/j.13652699.2005.01272.x.

Kevan, P. G. 1999. Pollinators as bioindicators of the state of the environment: species, activity and diversity. Agriculture, Ecosystems and Environment 74:373-393. https://doi.org/10.1016/B978-0-444-50019-9.50021-2.

Klein, A. M., B. M. Freitas, I. G. A. Bomfim, V. Boreux, F. Fornoff, and M. O. Oliveira. 2020. Insect pollination of crops in Brazil: a guide for farmers, gardeners, politicians and conservationists. Nature Conservation and Landscape Ecology, Albert-Ludwigs University Freiburg, Freiburg, Germany.

Koffler, S., C. Menezes, P. R. Menezes, A. M. P. Kleinert, V. L. Imperatriz-Fonseca, N. Pope, and R. Jaffé. 2015. Temporal variation in honey production by the stingless bee Melipona subnitida (Hymenoptera: Apidae): long-term management reveals its potential as a commercial species in Northeastern Brazil. Journal of Economic Entomology 108:858-867. 
https://doi.org/10.1093/jee/tov055.

Landaverde-González, P., J. J. G. Quezada-Euán, P. Theodorou, T. E. Murray, M. Husemann, R. Ayala, H. Moo-Valle, R. Vandame, and R. J. Paxton. 2017. Sweat bees on hot chillies: provision of pollination services by native bees in traditional slash-and-burn agriculture in the Yucatán Peninsula of tropical México. Journal of Applied Ecology 54: 1814-1824. https://doi.org/10.1111/1365-2664.12860.

Leguizamón, A. 2014. Modifying Argentina: GM soy and socio-environmental change. Geoforum 53:149-160. https: //doi.org/10.1016/j.geoforum.2013.04.001.

Leguizamón, A. 2016. Disappearing nature? Agribusiness, biotechnology and distance in Argentine soybean production. The Journal of Peasant Studies 43(2):313-330. https://doi.org/10.1080/03066150.2016.1140647.

Le Polain de Waroux, Y., M. Baumann, N. I. Gasparri, G. Gavier-Pizarro, J. Godar, T. Kuemmerle, R. Müller, F. Vázquez, J. N. Volante, and P. Meyfroidt. 2018. Rents, actors, and the expansion of commodity frontiers in the Gran Chaco. Annals of the American Association of Geographers 108(1):204-225. https://doi.org/10.1080/24694452.2017.1360761.

Lotta-Arévalo, I. A., M. A. Vargas-Ramírez, G. Nates-Parra, N. E. Matta, and R. Ospina Torres. 2020. Accediendo al pasado: uso de especímenes de colección como fuentes de información genética para el género Bombus (Hymenoptera: Apidae). Revista de Biología Tropical 68(2):394-414. https://doi.org/10.15517/rbt.v68i2.36350.

Lotta-Arévalo, I. A., M. A. Vargas-Ramírez, A. Parra-Hinojosa, G. Nates-Parra, N. E. Matta, G. Gennari, V. Stellfeldt, and R. Ospina-Torres. 2021. Genetic differentiation in a Neotropical species of Bombus (Hymenoptera: Apidae): Implications of translocations for pollinator conservation (en prensa).

Lopes, A. V., L. C. Girão, B. A. Santos, C. A. Peres, and M. Tabarelli. 2009. Long-term erosion of tree reproductive trait diversity in edge-dominated Atlantic Forest fragments. Biological Conservation 142:1154-1165. https://doi.org/ 10.1016/j.biocon.2009.01.007.

Lundin, O., M. Rundlöf, H. G. Smith, I. Fries, and R. Bommarco. 2015. Neonicotinoid insecticides and their impacts on bees: a systematic review of research approaches and identification of knowledge gaps. PLoS One 10:e0136928. https://doi.org/10.1371/journal.pone.0136928.

Magalhães, C. B., and B. M. Freitas. 2013. Introducing nests of the oil-collecting bee Centris analis (Hymenoptera: Apidae: Centridini) for pollination of acerola (Malpighia emarginata) increases yield. Apidologie 44:234-239. https: //doi.org/10.1007/s13592-012-0175-4.

Maggi, M., K. Antúnez, C. Invernizzi, P. Aldea, M. Vargas, P. Negri, C. Brasesco, D. De Jong, D. Message, E. Weinstein Teixeira, J. Principal, C. Barrios, S. Ruffinengo, R. Rodríguez Da Silva, and M. Eguaras. 2016. Honeybee health in South America. Apidologie 47(6):835-854. https://doi.org/10.1007/s13592-016-0445-7.

Maia-Silva, C., J. S. Pereira, B. M. Freitas, and M. Hrncir. 2021. Don't stay out too long! Thermal tolerance of the stingless bees Melipona subnitida decreases with increasing exposure time to elevated temperatures. Apidologie 52(1):218-229. https://doi.org/10.1007/s13592-020-00811-z.

Mantilla-Meluk, H., L. Siles, and L. F. Aguirre. 2014. Geographical and ecological amplitude in the nectarivorous bat Anoura fistulata (Phyllostomidae: Glossophaginae). Caldasia 36:373-388. https://doi.org/10.15446/caldasia.v36n2.47494.

MartínezLópez, O., J. B. Koch, M. A. MartínezMorales, D. NavarreteGutiérrez, E. Enríquez, and R. Vandame. 2021. Reduction in the potential distribution of bumble bees (Apidae: Bombus) in Mesoamerica under different climate change scenarios: Conservation implications. Global Change Biology 27(9):1772-1787. https://doi.org/10.1111/gcb.15559.

Mazzei, M. P., J. Vesprini, and L. Galetto. 2021. Seminatural habitats and their proximity to the crop enhances canola (Brassica napus) pollination and reproductive parameters in Argentina. Crop Science 61(4):2713-2721. https://doi.org/ $10.1002 /$ csc2.20450

McGuire, J. A., C. C. Witt, J. V. Remsen Jr., A. Corl, D. L. Rabosky, D. L. Altshuler, and R. Dudley. 2014. Molecular phylogenetics and the diversification of hummingbirds. Current Biology 24:910-916. https://doi.org/10.1016/ j.cub.2014.03.016.

Medan, D., J. P. Torretta, K. Hodara, E. B. de la Fuente Elba, and N. H. Montaldo. 2011. Effects of agriculture expansion and intensification on the vertebrate and invertebrate diversity in the Pampas of Argentina. Biodiversity and Conservation 20(13):3077-3100. https://doi.org/10.1007/s10531-011-0118-9.

Medina, R. G., R. J. Paxton, S. M. T. Hernández-Sotomayor, C. Pech-Jimenez, L. A. Medina-Medina, and J. J. G. Quezada-Euán. 2020 Heat stress during development affects immunocompetence in workers, queens and drones of Africanized honey bees (Apis mellifera L.) (Hymenoptera: Apidae). Journal of Thermal Biology 89:102541. https: //doi.org/10.1016/j.jtherbio.2020.102541.

Milfont, M. O., E. E. M. Rocha, A. O. N. Lima, and B. M. Freitas.2013. Higher soybean production using honeybee and wild pollinators, a sustainable alternative to pesticides and autopollination. Environmental Chemical Letters 11: 335-341. https://doi.org/10.1007/s10311-013-0412-8.

Miranda, L. S., V. L. Imperatriz-Fonseca, and T. C. Giannini. 2019. Climate change impact on ecosystem functions provided by birds in southeastern Amazonia. Plos One 14(4):e0215229. https://doi.org/10.1371/journal.pone.0215229.

Mitchell, E. A., B. Mulhauser, M. Mulot, A. Mutabazi, G. Glauser, and A. Aebi. 2017. A worldwide survey of neonicotinoids in honey. Science 358:109-111. https://doi.org/10.1126/science.aan3684.

Mokkapati, J. S., A. J. Bednarska, and R. Laskowski. 2021. The development of the solitary bee Osmia bicornis is affected by some insecticide agrochemicals at environmentally relevant concentrations. Science of the Total Environment 775 : 145588. https://doi.org/10.1016/j.scitotenv.2021.145588.

Molin, P. G., S. E. Gergel, B. S. Soares-Filho, and S. F. Ferraz. 2017. Spatial determinants of Atlantic Forest loss and recovery in Brazil. Landscape Ecology 32:857-870. https://doi.org/10.1007/s10980-017-0490-2.

Montalva, J., V. Sepulveda, F. Vivallo, and S. D. Paiva. 2017. New records of an invasive bumble bee in northern Chile: 
expansion of its range or new introduction events? Journal of Insect Conservation 21:657-666. https://doi.org/10.1007/ s10841-017-0008-x.

Mora-Beltrán, C., and H. F. López-Arévalo. 2018. Interactions between bats and floral resources in a premontane forest, Valle del Cauca, Colombia. Therya 9(2):129-136. https://doi.org/10.12933/therya-18-560.

Morales, C. L., A. Sáez, L. A. Garibaldi, and M. A. Aizen. 2017. Disruption of pollination services by invasive pollinator species. Pp. 203-220 in M. Vilà and P. E. Hulme (eds.). Impact of biological invasions on ecosystem services. Springer International Publishing. Cham, Switzerland. https://doi.org/10.1007/978-3-319-45121-3_13.

Moure, J. M., D. Urban, and G. A. R Melo. 2007. Catalogue of bees (Hymenoptera, Apoidea) in the Neotropical Region. Sociedade Brasileira de Entomologia, Curitiba, Brasil.

Nates-Parra, G. (ed.). 2017. Iniciativa Colombiana de Polinizadores-Abejas-ICPA. Bogotá, D.C. Departamento de biología, Universidad Nacional de Colombia. Colombia.

Nates, G., and B. Ramirez. 2020. Guía para la conservación y manejo de abejas sin aguijón Melipona favosa. Convenio La Miel de la Biodiversidad. Yopal, Casanare, Colombia.

Nemésio, A., D. P. Silva, J. C. Nabout, and S. Varela. 2016. Effects of climate change and habitat loss on a forestdependent bee species in a tropical fragmented landscape. Insect Conservation and Diversity 9:149-160. https: //doi.org/10.1111/icad.12154.

Nicodemo, D., D. De Jong, L. G. Reis, J. M. V. D. Almeida, A. A. D. Santos, and L. A. M. Lisboa. 2018. Transgenic corn decreased total and key storage and lipid transport protein levels in honey bee hemolymph while seed treatment with imidacloprid reduced lipophorin levels. Journal of Apicultural Research 57:321-328. https://doi.org/10.1080/ 00218839.2017.1391530.

Ollerton, J. 2017. Pollinator diversity: distribution, ecological function, and conservation. Annual Review of Ecology, Evolution, and Systematics 48:353-376. https://doi.org/10.1146/annurev-ecolsys-110316-022919.

Orr, M. C., A. C. Hughes, D. Chesters, J. Pickering, C. D. Zhu, and J. S. Ascher. 2021. Global patterns and drivers of bee distribution. Current Biology 31(3):451-458. https://doi.org/10.1016/j.cub.2020.10.053.

Ospina-Torres, R., J. Medina, R. Ramírez, G. Nates-Parra, M. Amaya, D. Melo, and C. Angel. 2010. Eficiencia de las abejas polinizadoras de los cultivos de gulupa (Passiflora edulis Sims) y granadilla (Passiflora ligularis Juss) en Buenavista, Boyacá, Colombia. Memorias I Congreso Latinoamericano de Passiflora, Neiva, Huila, Colombia.

Pandolfo, C. E., A. Presotto, F. T. Carbonell, S. Ureta, M. Poverene, and M. Cantamutto. 2018. Transgene escape and persistence in an agroecosystem: the case of glyphosate-resistant Brassica rapa L. in central Argentina. Environmental Science and Pollution Research 25:6251-6264. https://doi.org/10.1007/s11356-017-0726-3.

Pendrill, F., and U. M. Persson. 2017 Combining global land cover datasets to quantify agricultural expansion into forests in Latin America: Limitations and challenges. Plos One 12(7):e0181202. https://doi.org/10.1371/journal.pone.0181202.

Pengue, W. A. 2005. Transgenic crops in Argentina: the ecological and social debt. Bulletin of Science, Technology and Society 25:314-322. https://doi.org/10.1177/0270467605277290.

Pengue, W. A., and M. A. Altieri. 2005. La soja transgénica en América Latina. Una maquinaria de hambre, deforestación y devastación socioecológica. Ecología Política 30:87-94.

Pengue, W. A. 2016. Recursos, transición socioecológica y política ambiental. Fronteras 14: 17-37.

Pisa, L., D. Goulson, E. C. Yang, D. Gibbons, F. Sánchez-Bayo, E. Mitchell, A. Aebi, J. van der Sluijs, C. J. K. MacQuarrie, C. Giorio, E. Yim Long, M. McField, M. Bijleveld van Lexmond, and J.-M. Bonmatin. 2017. An update of the Worldwide Integrated Assessment (WIA) on systemic insecticides. Part 2: impacts on organisms and ecosystems. Environmental Science and Pollution Research 1-49. https://doi.org/10.1007/s11356-017-0341-3.

Plischuk, S., K. Antúnez, M. Haramboure, G. M. Minardi, and C. E. Lange. 2017. Longterm prevalence of the protists Crithidia bombi and Apicystis bombi and detection of the microsporidium Nosema bombi in invasive bumble bees. Environmental Microbiology Reports 9(2):169-173. https://doi.org/10.1111/1758-2229.12520.

Poot-Baez, V., R. Medina-Hernández, S. Medina-Peralta, and J. J. G. Quezada-Euán. 2020. Intranidal temperature and body size of Africanized honey bees under heatwaves (Hymenoptera: Apidae). Apidologie 51:382-390. https: //doi.org/10.1007/s13592-019-00725-5.

Potts, S. G., V. Imperatriz-Fonseca, H. T. Ngo, M. A. Aizen, J. C. Biesmeijer, T. D. Breeze, L. V. Dicks, L. A. Garibaldi, R. Hill, J. Settele, and A. J. Vanbergen. 2016. Safeguarding pollinators and their values to human well-being. Nature 540(7632): 220-229. https://doi.org/10.1038/nature20588.

Quezada-Euán, J. J. G., W. de Jesús May-Itzá, and J. A. González-Acereto. 2001. Meliponiculture in México: problems and perspective for development. Bee World 82(4):160-167. https://doi.org/10.1080/0005772X.2001.11099523.

Quezada-Euán, J. J. G., G. Nates-Parra, M. M. Maués, D. W. Roubik, and V. L. Imperatriz-Fonseca. 2018. The economic and cultural values of stingless bees (Hymenoptera: Meliponini) among ethnic groups of tropical America. Sociobi ology 65(4):534-557. https://doi.org/10.13102/sociobiology.v65i4.3447.

Rahimi, E., S. Barghjelveh, and P. Dong. 2021. How effective are artificial nests in attracting bees? A review. Journal of Ecology and Environment 45(1):1-11. https://doi.org/10.1186/s41610-021-00192-z.

Riaño, D., and J. R. Cure. 2016. Efecto letal agudo de los insecticidas en formulación comercial Imidacloprid, Spinosad y Thiocyclam hidrogenoxalato en obreras de Bombus atratus (Hymenoptera: Apidae). Revista de Biología Tropical 64(4):1737-1745. https://doi.org/10.15517/rbt.v64i4.21521.

Ricroch, A., S. Akkoyunlu, J. Martin-Laffon, and M. Kuntz. 2018. Assessing the environmental safety of transgenic plants: honey bees as a case study. Advances in Botanical Research 86:111-167. https://doi.org/10.1016/bs.abr.2017.11.004.

Rozzi, R. 2013. Biocultural ethics: from biocultural homogenization toward biocultural conservation. Pp. 9-32 in R. 
Rozzi, S. T. Pickett, C. Palmer, J. J. Armesto and J. B. Callicott (eds.). Linking ecology and ethics for a changing World. Springer, Dordrecht, Germany. https://doi.org/10.1007/978-94-007-7470-4_2.

Rubio, F., E. Guo, and L. Kamp. 2014. Survey of glyphosate residues in honey, corn and soy products. Journal of Environmental Analytical Toxicology 5:1.

Rundlöf, M., G. K. Andersson, R. Bommarco, I. Fries, V. Hederström, L. Herbertsson, O. Jonsson, B. K. Klatt, T. R. Pedersen, J. Yourstone, and H. G. Smith. 2015. Seed coating with a neonicotinoid insecticide negatively affects wild bees. Nature 521(7550):77-80. https://doi.org/10.1038/nature14420.

Sáez, A., M. Sabatino, and M. A. Aizen. 2012. Interactive effects of large- and small-scale sources of feral honey-bees for sunflower in the Argentine Pampas. Plos One 7:e30968. https://doi.org/10.1371/journal.pone.0030968.

SchmidHempel, R., M. Eckhardt, D. Goulson, D. Heinzmann, C. Lange, S. Plischuk, L. R. Escudero, R. Salathe J. J. Scriven and P. SchmidHempel. 2014. The invasion of southern South America by imported bumblebees and associated parasites. Journal of Animal Ecology 83:823-837. https://doi.org/10.1111/1365-2656.12185.

Silva, J. L. S. E., O. Cruz-Neto, C. A. Peres, M. Tabarelli, and A. V. Lopes. 2019. Climate change will reduce suitable Caatinga dry forest habitat for endemic plants with disproportionate impacts on specialized reproductive strategies. Plos One 14(5):e0217028. https://doi.org/10.1371/journal.pone.0217028.

Smith, M. R., G. M. Singh, D. Mozaffarian, and S. S. Myers. 2015. Effects of decreases of animal pollinators on human nutrition and global health: a modelling analysis. The Lancet 386(10007):1964-1972. https://doi.org/10.1016/S01406736(15)61085-6.

Torres-Ruiz, A., and R. W. Jones. 2012. Comparison of the efficiency of the bumble bees Bombus impatiens and Bombus ephippiatus (Hymenoptera: Apidae) as pollinators of tomato in greenhouses. Journal of Economic Entomology 105: 1871-1877. https://doi.org/10.1603/EC12171.

Tremlett, C. J., M. Moore, M. A. Chapman, V. ZamoraGutiérrez, and K. S. H. Peh. 2020. Pollination by bats enhances both quality and yield of a major cash crop in México. Journal of Applied Ecology 57(3):450-459. https://doi.org/ 10.1111/1365-2664.13545.

Vandame, R., and M. A. Palacio. 2010. Preserved honey bee health in Latin America: a fragile equilibrium due to lowintensity agriculture and beekeeping? Apidologie 41:243-255. https://doi.org/10.1051/apido/2010025.

Viana, B. F., F. O. Silva, G. Castagnino, J. G. Coutinho, K. P. Gramacho, and L. A. Garibaldi. 2014. Stingless bees further improve apple pollination and production. Journal of Pollination Ecology 14:261- 269. https://doi.org/10.26786/19207603(2014)26.

Villanueva-Gutiérrez, R., C. Echazarreta-González, D. W. Roubik, and Y. B. Moguel-Ordóñez. 2014. Transgenic soybean pollen (Glycine max L.) in honey from the Yucatan península, México. Scientific Reports 4:4022. https: //doi.org/10.1038/srep04022.

Vryzas, Z., C. Ramwell, and C. Sans. 2020. Pesticide prioritization approaches and limitations in environmental monitoring studies: From Europe to Latin America and the Caribbean. Environment International 143:105917. https: //doi.org/10.1016/j.envint.2020.105917.

Witter, S., P. Nunes-Silva, B. B. Lisboa, F. P. Tirelli, A. Sattler, S. Both Hilgert-Moreira, and B. Blochtein. 2015. Stingless bees as alternative pollinators of canola. Journal of Economic Entomology 108(3):880-886. https://doi.org/10.1093/ jee/tov096.

Wolowski, M., K. Agostini, A. R. Rech, I. G. Varassin, M. Maueìs, L. Freitas, L. T. Carneiro, R. O. Bueno, H. Consolaro, L. Carvalheiro, A. M. Saraiva, C. I. Silva, and M. C. G. Padgurschi (org.). 2019. 1a edicaPo. BPBES/ REBIPP. Relatoìrio temaitico sobre Polinizacapo, Polinizadores e ProducaPo de Alimentos no Brasil. Editora Cubo, SaPo Carlos, SP, Brasil. https://doi.org/10.4322/978-85-60064-83-0.

Yamamoto, M., C. I. da Silva, S. C. Augusto, A. A. A. Barbosa, and P. E. Oliveira. 2012. The role of bee diversity in pollination and fruit set of yellow passion fruit (Passiflora edulis forma flavicarpa, Passifloraceae) crop in Central Brazil. Apidologie 43(5):515-526. https://doi.org/10.1007/s13592-012-0120-6.

Yanai, A. M., E. M. Nogueira, P. M. L. de Alencastro, and P. M. Fearnside. 2017. Deforestation and carbon stock loss in Brazil's Amazonian settlements. Environmental Management 59:393-409. https://doi.org/10.1007/s00267-016-07832.

Yurrita, C. L., M. A. Ortega-Huerta, and R. Ayala. 2017. Distributional analysis of Melipona stingless bees (Apidae: Meliponini) in Central America and México: setting baseline information for their conservation. Apidologie 48:247258. https://doi.org/10.1007/s13592-016-0469-z.

ZamoraGutiérrez, V., A. N. RiveraVillanueva, S. Martínez Balvanera, A. CastroCastro, and J. AguirreGutiérrez. 2021. Vulnerability of bat-plant pollination interactions due to environmental change. Global Change Biology 27(14):33673382. https://doi.org/10.1111/gcb.15611 